\title{
Review Article \\ The Epidemiology and Demographics of Slipped Capital Femoral Epiphysis
}

\author{
Randall T. Loder ${ }^{1,2}$ and Elaine N. Skopelja ${ }^{3}$ \\ ${ }^{1}$ Riley Children's Hospital, Room 4250, 705 Riley Hospital Drive, Indianapolis, IN 46202, USA \\ ${ }^{2}$ Department of Orthopaedic Surgery, Indiana University, Indianapolis, IN 46202, USA \\ ${ }^{3}$ Ruth Lilly Medical Library, Indiana University School of Medicine, Indianapolis, IN 46202, USA
}

Correspondence should be addressed to Randall T. Loder, rloder@iupui.edu

Received 15 May 2011; Accepted 11 June 2011

Academic Editors: C.-H. Lee, C. Mathoulin, K. S. Song, and H. Yuan

Copyright ( 2011 R. T. Loder and E. N. Skopelja. This is an open access article distributed under the Creative Commons Attribution License, which permits unrestricted use, distribution, and reproduction in any medium, provided the original work is properly cited.

\begin{abstract}
The etiology of slipped capital femoral epiphysis (SCFE) is unknown with many insights coming from epidemiologic/demographic information. A systematic medical literature review regarding SCFE was performed. The incidence is $0.33 / 100,000$ to $24.58 / 100,000$ children 8 to 15 years of age. The relative racial frequency, relative to Caucasians at 1.0, is 5.6 for Polynesians, 3.9 for Blacks, and 2.5 for Hispanics. The average age is 12.0 years for boys and 11.2 years for girls. The physiologic age when SCFE occurs is less variable than the chronologic age. The average symptom duration is 4 to 5 months. Most children are obese: $>50 \%$ are $>95$ th percentile weight for age with average BMI is $25-30 \mathrm{~kg} / \mathrm{m}^{2}$. The onset of SCFE is in the summer when north of $40^{\circ} \mathrm{N}$. Bilaterality ranges from 18 to 50\%. In children with bilateral involvement, 50-60\% present with simultaneous SCFEs and those who present with a unilateral SCFE and subsequently develop a contralateral SCFE do so within 18 months. The age at presentation is younger for those who present with a unilateral SCFE and later develop a contralateral SCFE. The age-weight, age-height, and height test are useful to differentiate between an idiopathic and atypical SCFE.
\end{abstract}

\section{Introduction}

Slipped capital femoral epiphysis (SCFE) is an adolescent hip disorder with displacement of the capital femoral epiphysis from the metaphysis through the physis. Most SCFEs are varus (medial and posterior epiphyseal displacement relative to the metaphysic) but can occasionally be valgus (lateral and superior epiphyseal displacement) [1-4]. The vast majority are "idiopathic"; atypical SCFEs are those that occur due to an endocrine disorder [5-7], renal failure osteodystrophy $[8]$, or radiation therapy $[7,9,10]$. The literature regarding the epidemiology and demographics of SCFE first requires a general knowledge of the disorder.

SCFE is classified both clinically and by severity. The traditional clinical classification was acute, chronic, and acute on chronic [12-16], based on the patient's history, physical examination, and roentgenograms. An acute SCFE is defined as those with symptoms for $<3$ weeks with an abrupt displacement through the proximal physis [12]. Chronic SCFEs present $\geq 3$ weeks of symptoms and account for $85 \%$ of all SCFEs [17]. Acute-on-chronic SCFEs are those with chronic symptoms initially and the subsequent development of acute symptoms. Newer classifications are more clinically useful, depend upon physeal stability, and predict the prognosis regarding subsequent avascular necrosis. There are two such classifications: one clinical and one radiographic. The clinical classification depends upon the ability of the child to ambulate [18]. A stable SCFE is defined as one where the child is able to ambulate, with or without crutches. An unstable SCFE is defined as one where the child cannot ambulate, with or without crutches. The radiographic classification depends upon the presence or absence of a hip effusion on ultrasonography $[19,20]$. The absence of metaphyseal remodeling and the presence of an effusion define an unstable SCFE; metaphyseal remodeling and the absence of an effusion define a stable SCFE. Unstable SCFEs have a much higher incidence of avascular necrosis (up to $50 \%$ in some series) compared to stable SCFEs (nearly $0 \%$ ) [18]. 


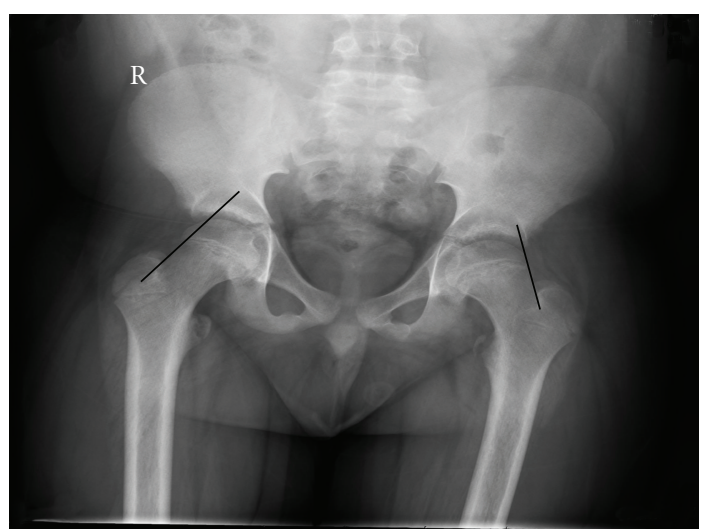

Figure 1: A normal and abnormal epiphyseal line as described by Klein et al. [11] in an 11 year 6 month old boy with a left SCFE. In this anterior-posterior pelvis radiograph proximal prolongation of the superior neck line transects the epiphysis in the normal hip (right) but either lies flush with or does not transect the epiphysis in SCFE (left hip).

Radiographs demonstrate an inferior and posterior slip of the proximal femoral epiphysis relative to the metaphysis. The gradual slip demonstrates radiographic signs of remodeling on the superior and anterior femoral metaphysis, and periosteal new-bone formation at the epiphysealmetaphyseal junction posteriorly and inferiorly. In the early slip, the changes can be subtle with only posterior displacement [21]. As such it is usually seen early only on the lateral view, and both anteroposterior and lateral radiographs must be obtained. Other radiographic signs of an early SCFE are the metaphyseal blanch sign of Steel [22] and Klein's line [11]. The metaphyseal blanch sign of Steel is a radiographic double density seen on the anteroposterior view at the level of the metaphysis; this double density reflects the posterior cortical lip of the epiphysis as it is beginning to slip posteriorly and is radiographically superimposed upon the metaphyseal density. Klein's line is drawn along the anterior or superior aspect of the femoral neck; the epiphysis should normally intersect this line. In an early SCFE the epiphysis will be flush with or even below this line (Figure 1).

SCFE severity is described by two different methods. The first is the amount of displacement of the epiphysis on the metaphysis (Figure 2). A mild SCFE is defined as epiphysealmetaphyseal displacement $<1 / 3$ the width of the metaphysis; a moderate SCFE $1 / 3-1 / 2$; a severe SCFE $>1 / 2$ (Figure 2(a)) [23]. This method is less accurate than angular measurement since distinct landmarks are difficult to determine due to metaphyseal remodeling in the gradual stable SCFE [24]. Angular measurement uses the epiphyseal-shaft angle on the frog-lateral radiograph [25] (Figure 2(b)) and is categorized into 3 groups: mild $<30^{\circ}$, moderate $30-50^{\circ}$, and severe $>50^{\circ}$ [16]. This classification is important for long-term prognosis as mild and moderate slips have a much better long-term prognosis than severe slips which demonstrate a more rapid development of degenerative hip disease [26, 27]. CT scan measurements are no more accurate than those using conventional radiographs [28].

\section{Materials and Methods}

A systematic review of SCFE was performed. SCFE has been known by many different names since its first description in the late 19th and early 20th centuries. Prior to the last 40 years or so, the accepted name for this condition had been very inconsistent. Even now there is no actual MESH (Medical Subject Heading) term for slipped capital femoral epiphysis (SCFE). Users must combine "epiphyses, slipped" and "femur head". The modern, most used, frequently used term "slipped capital femoral epiphysis" or SCFE, must be searched as a keyword phrase. To ensure capture of all the published literature, older terms were also searched as keywords or keyword phrases. Therefore the terms used to search for SCFE were slipped capital femoral epiphysis, slipped epiphysis, epiphysiolysis, and epiphysiolyses. The last strategy was to combine these two sets of terms: (slipped OR slipping OR sliding OR displaced OR displacement OR detached OR detachment OR separated OR separation) combined with (femur OR head OR capitis OR epiphysis OR epiphyseal OR epiphysiolysis OR epiphysiolyses).

The databases searched were PubMed (1947-2010) (http ://www.ncbi.nlm.nih.gov/pubmed/), Ovid Medline (19472010), EMBASE (1947-2010), WorldCat (1880-2010) (books and theses) (http://firstsearch.oclc.org/), Google Scholar (1880-2010) (http://scholar.google.com/), Web of Knowledge (1987-2010), and IndexCat (1880-1961) (Index Catalogue of the Library of the Surgeon-General's Office) (http://www.indexcat.nlm.nih.gov/). Exclusion criteria were those manuscripts discussing surgery, therapy, rehabilitation, and any foreign language articles without an English abstract. Individual orthopaedic journals were also searched for articles published prior to 1966 that predate electronic Medline indexing, including Journal of Bone and Joint Surgery (American and British), Clinical Orthopaedics and Related Research, and Acta Orthopaedica Scandinavica. Age groups were limited to those $<18$ years old; duplicate citations were removed.

This search resulted in 1407 unique citations. These 1407 manuscripts were reviewed to find those that discussed any of the topics regarding SCFE and epidemiology, demographics, incidence, prevalence, race, gender, family history, inheritance, genetics, age, bone age, weight (either birth weight or normal weight), height, growth, maturation, any other anthropometric characteristics, seasonal variation, hormone, endocrine, congenital anomalies, collagen, immunoglobulin, and opposite hip. Of these 1407 manuscripts, 114 provided ample information and are the contents of this paper.

\section{Results}

3.1. Incidence. Conventional quotation for SCFE incidence in the literature is the number of cases per 100,000 (usually for the age range 8 to 15 years old, although some use $<25$ years of age) and is used throughout this paper. The incidence (Table 1) ranges from 0.2 per 100,000 in eastern Japan [36] to 17.15 in the Northeastern United States [31]. Recent studies indicate that the overall incidence in the 


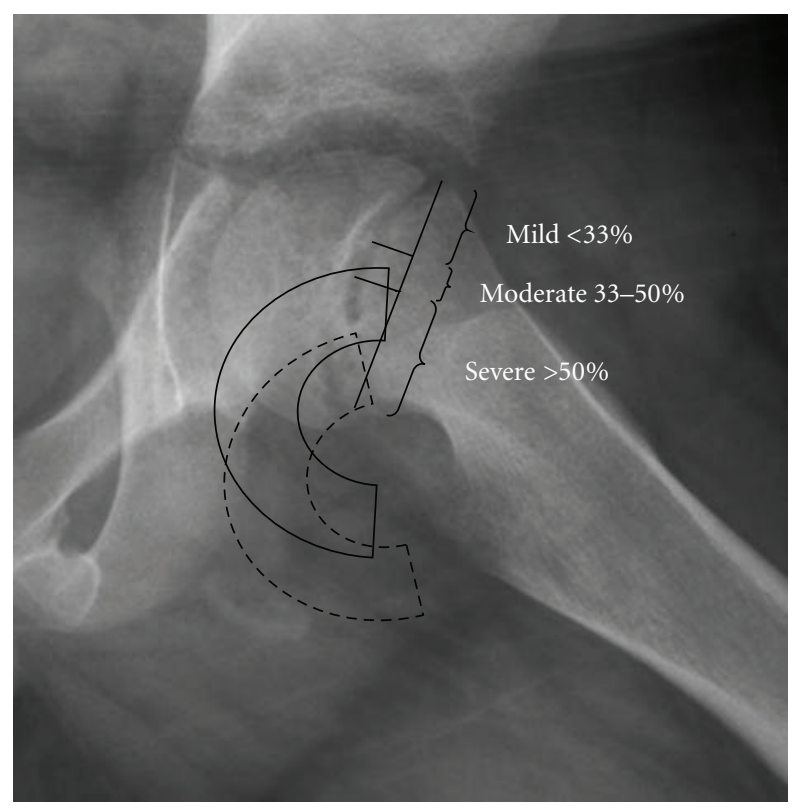

(a)

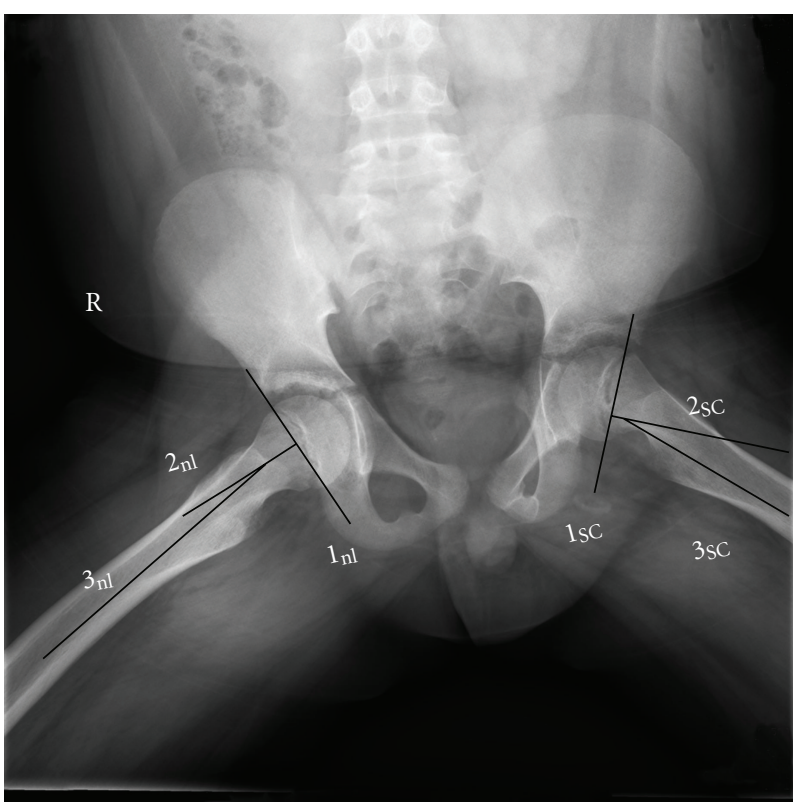

(b)

FIGURE 2: The two different methods of assessing SCFE severity. (a) The amount of displacement of the epiphysis relative to the metaphysis. A mild SCFE is defined as epiphyseal-metaphyseal displacement $<1 / 3$ the width of the metaphysis; a moderate SCFE $1 / 3-1 / 2$; a severe SCFE as $>1 / 2$ [23]. In this case the SCFE is mild. The position of the epiphysis in a moderate SCFE is represented by the solid semicircle and in a severe SCFE by the hatched semicircle. (b) The lateral epiphyseal shaft angle measurement as described by Southwick [25] on the frog lateral radiograph. The frog lateral radiograph of the case in Figure 1 is shown. Both the normal hip (nl) and SCFE hip (SC) are measured. Line 1 is the line between the anterior and posterior physis, line 2 is a perpendicular to line 1 , and the intersection of line 2 with an axial line along the shaft of the femur (line 3) is the epiphyseal shaft angle. The slip angle is calculated by subtracting the epiphyseal shaft angle of the normal hip from the slip side. Those less than 30 degrees are considered mild, between 30 and 50 degrees moderate, and greater than 50 degrees severe. The severity of the SCFE is the lateral epiphyseal shaft angle of the normal hip subtracted from the SCFE hip. In this example the slip angle is $25^{\circ}-10^{\circ}$ or $15^{\circ}$.

United States is $10.8 / 100,000$ [31], similar to 10.08 in boys in the Kelsey et al.'s study [37]. In Japan it has increased to $2.22 / 100,000$ for boys and $0.76 / 100,000$ for girls [38]. In Olmsted County, Minnesota, the incidence was $8.8 ; 8.3$ for unilateral cases and 0.5 for bilateral cases [39]. The incidence is increasing in some areas compared to previous reports; in New Mexico [32] it has nearly tripled (6.05 versus 2.13) compared to an earlier study [37]. In Scotland, the incidence has increased from 3.78 in 1981 to 9.66 in 2000, correlated with rising obesity [40]. The highest presently quoted incidence is in US Africans at 24.58 [31].

There is little data regarding differences between urban and rural areas. The incidence of SCFE in southern Sweden increased in rural areas for boys (7.5 versus 4.8$)$ but decreased for girls (2.2 versus 3.8) [34]. No differences were noted in Connecticut in white children between urban and nonurban settings (3.19 for both) [41] although there was an increased incidence in Africans living in urban areas compared to nonurban areas (7.95 versus 1.35 ). No differences were noted by gender.

In the USA there are differences by geographic region. In a recent study [31] the highest incidence was in the Northeast at 17.15 and the lowest in the Midwest at 7.69. This is similar to an earlier study [37] where the incidence in the Northeast was 10.08 and 2.13 in New Mexico.

3.2. Race/Ethnicity. There is significant racial variability with SCFE (Table 2). Race is classified using the definitions of Eveleth and Tanner: Caucasians, Africans in Africa and of African Ancestry, Asiatics (Amerindians, Hispanics, Indonesian-Malays), Indo-Mediterraneans (inhabitants of the Near East, North Africa, and Indian subcontinent), and Australian Aborigines and Pacific Island peoples [53]. The relative racial frequency (RRF) of SCFE, with Whites at 1.0, is 4.5 for Pacific Islanders, 2.2 for Africans, 1.05 for Amerindian (Native Americans and Hispanics), 0.5 for IndonesianMalay (Chinese, Japanese, Thai, Vietnamese, etc.), and 0.1 for Indo-Mediterranean peoples (Near East, North African, or Indian subcontinent ancestry) [30]. More recent data indicates that these numbers, relative to Caucasians, is 5.6 for Polynesians, 3.9 for Blacks, and 2.5 for Hispanics (Figure 3(a)) $[29,31]$. In New Zealand the RRF was 5.6 for the Maori peoples and 4.2 for other Pacific Islanders [29]. In Singapore the RRFs, relative to Chinese, are 9.6 for IndoMediterraneans (Indian), 2.8 for Malay, and 3.0 for mixed (Eurasians) (Figure 3(b)) [33]. Thus Indo-Mediterraneans 
TABLE 1: Incidence of slipped capital femoral epiphysis*

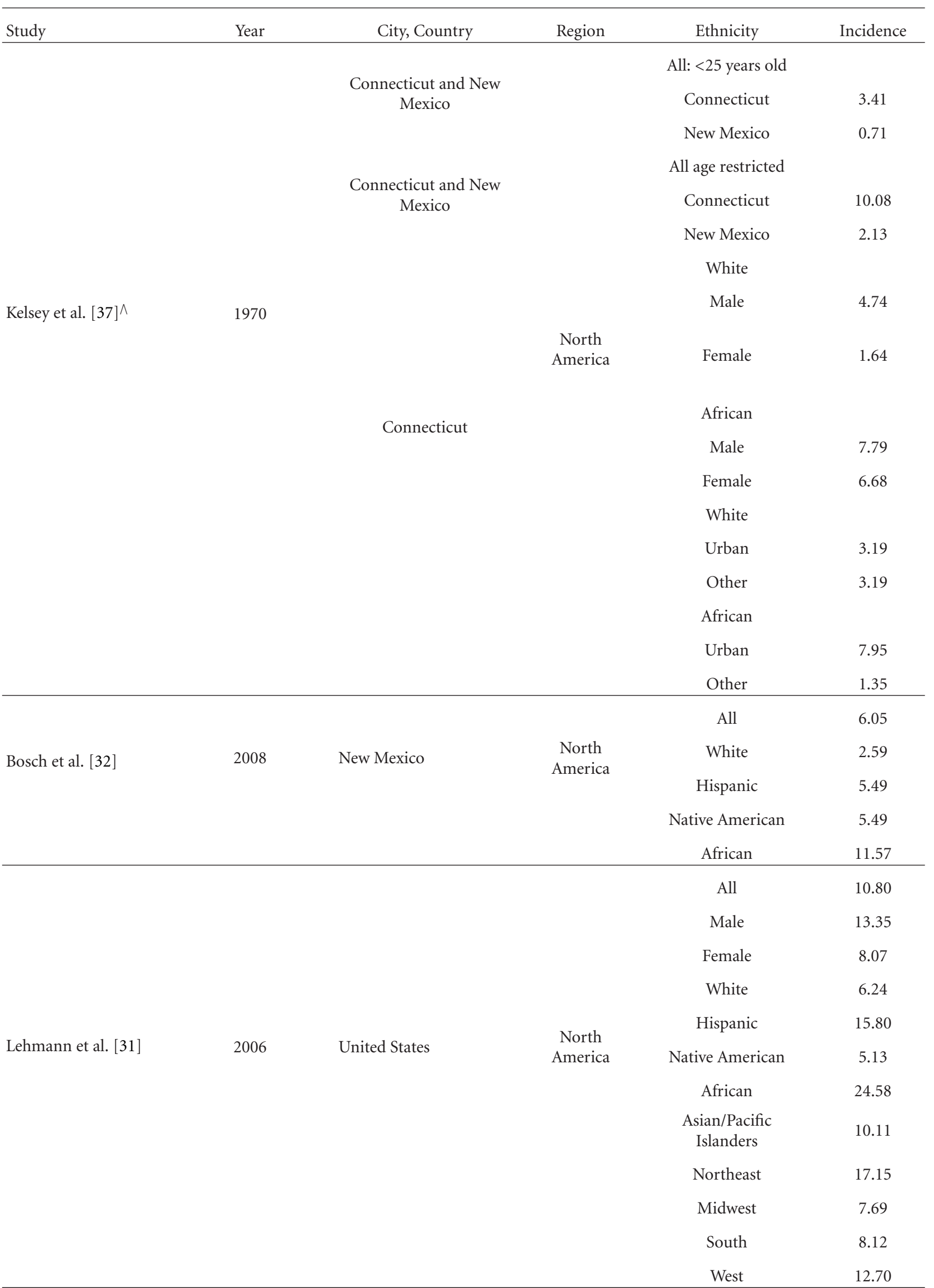


TABle 1: Continued.

\begin{tabular}{|c|c|c|c|c|c|}
\hline Study & Year & City, Country & Region & Ethnicity & Incidence \\
\hline Larson et al. [39] & 2010 & Minnesota & $\begin{array}{l}\text { North } \\
\text { America }\end{array}$ & All & 8.8 \\
\hline \multirow{3}{*}{ Jerre et al. [42] } & \multirow{3}{*}{1996} & \multirow{3}{*}{ Gothenburg, Sweden } & \multirow{3}{*}{ Scandinavia } & All & 7.1 \\
\hline & & & & Male & 9.0 \\
\hline & & & & Female & 5.1 \\
\hline Henrikson [43] & 1969 & Gothenburg, Sweden & Scandinavia & All & 8.2 \\
\hline \multirow{9}{*}{ Hägglund et al. [34] } & \multirow{9}{*}{1984} & \multirow{9}{*}{ Southern Sweden } & \multirow{9}{*}{ Scandinavia } & All & \\
\hline & & & & Male & 7.1 \\
\hline & & & & Female & 5.3 \\
\hline & & & & Rural & \\
\hline & & & & Male & 7.5 \\
\hline & & & & Female & 2.2 \\
\hline & & & & Urban & \\
\hline & & & & Male & 4.8 \\
\hline & & & & Female & 3.8 \\
\hline \multirow[t]{2}{*}{$\begin{array}{l}\text { Murray and Wilson } \\
{[40]}\end{array}$} & \multirow[t]{2}{*}{2008} & \multirow[t]{2}{*}{ Scotland } & \multirow[t]{2}{*}{ Europe } & $\begin{array}{c}\text { All } \\
1981\end{array}$ & 3.78 \\
\hline & & & & 2000 & 9.66 \\
\hline \multirow{3}{*}{$\begin{array}{l}\text { Noguchi and Sakamaki } \\
\text { [38] }\end{array}$} & \multirow{3}{*}{2002} & \multirow{3}{*}{ Japan } & \multirow{3}{*}{ Asia } & All & 1.51 \\
\hline & & & & Male & 2.22 \\
\hline & & & & Female & 0.76 \\
\hline Lim et al. [33] & 2008 & Singapore & Asia & All & 1.2 \\
\hline Ninomiya et al. [36] & 1976 & Japan & Asia & All & 0.25 \\
\hline \multirow{3}{*}{ Song et al. [44] } & \multirow{3}{*}{2009} & \multirow{3}{*}{ Korea } & \multirow{3}{*}{ Asia } & All & 0.33 \\
\hline & & & & Male & 0.50 \\
\hline & & & & Female & 0.14 \\
\hline
\end{tabular}

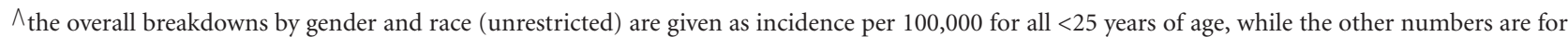
boys $10-17$ years old and girls $8-15$ years old.

* incidence for children $8-15$ years of age.

(Indian) had a 9-fold increased incidence compared to IndoMalay (Chinese). This is in contrast to another study [30] where Indo-Mediterraneans had a 5 times lower frequency of SCFE compared to Indo-Malays (all groups-Japanese, Thai). These racial differences most likely reflect the average body weights for each racial group and further support the significant role that obesity and mechanical stress plays in the etiology of SCFE [30]. A less likely explanation is racial variability in acetabular depth and femoral head coverage; the acetabulae in African children were deeper than White children in one study [54], but not in another study [55].
3.3. Gender and Age. Most series demonstrate a male predominance. Early in this century $90 \%$ occurred in males [57] but has now decreased to $\sim 60 \%$. In a review of 4343 children, $64.3 \%$ were boys and $35.7 \%$ girls (Table 3 ). There are differences in gender by race, with Indo-Mediterraneans having the highest proportion of boys (90\%) and Polynesians an equal male/female ratio [30].

SCFE is a disease of prepubescence and early adolescence. Early in this century the average age was much higher with a gradual decrease over time (Figure 4(a)). Fifteen years ago the average age was 13.5 years for boys and 
TABLE 2: (a) relative racial frequencies of $\mathrm{SCFE}^{\wedge}$, (b) relative racial frequencies of $\mathrm{SCFE}^{+}$.

(a)

\begin{tabular}{|c|c|c|c|c|c|}
\hline Study & Year & City, Country & Region & Race & RRF \\
\hline \multirow{2}{*}{ Kelsey et al. [37] } & \multirow{2}{*}{1970} & & \multirow[b]{2}{*}{ North America } & African & 2.31 \\
\hline & & & & White & 1.0 \\
\hline \multirow{4}{*}{ Bosch et al. [32] } & \multirow{4}{*}{2008} & \multirow{4}{*}{ New Mexico } & \multirow{4}{*}{ North America } & African & 4.47 \\
\hline & & & & Hispanic & 2.12 \\
\hline & & & & Native American & 2.12 \\
\hline & & & & White & 1.0 \\
\hline \multirow{4}{*}{ Lehmann et al. [31] } & \multirow{4}{*}{2006} & \multirow{4}{*}{ United States } & \multirow{4}{*}{ North America } & African & 3.94 \\
\hline & & & & Hispanic & 2.53 \\
\hline & & & & Asian/Pacific Islanders & 1.62 \\
\hline & & & & White & 1.0 \\
\hline \multirow{3}{*}{$\begin{array}{l}\text { Stott and Bidwell } \\
\text { [29] }\end{array}$} & \multirow{3}{*}{2003} & \multirow{3}{*}{ New Zealand } & \multirow{3}{*}{ Australia/NZ } & New Zealand Maori & 5.6 \\
\hline & & & & Pacific & 4.2 \\
\hline & & & & White & 1.0 \\
\hline \multirow{6}{*}{ Loder [30] } & \multirow{6}{*}{1996} & \multirow{6}{*}{ Worldwide } & & NA/Pacific Islanders & 4.5 \\
\hline & & & & African & 2.2 \\
\hline & & & & Hispanic/Native Am & 1.05 \\
\hline & & & & White & 1.0 \\
\hline & & & & Indo-Malay & 0.5 \\
\hline & & & & Indo-Med & 0.1 \\
\hline
\end{tabular}

$\Lambda_{\text {using Caucasian as a baseline frequency of 1.0. }}$

(b)

\begin{tabular}{|c|c|c|c|c|c|}
\hline Study & Year & City, Country & Region & Race & RRF \\
\hline \multirow{4}{*}{$\begin{array}{l}\text { Lim et al. } \\
\text { [33] }\end{array}$} & \multirow{4}{*}{2008} & \multirow{4}{*}{ Singapore } & \multirow{4}{*}{ Asia } & Indian & 9.6 \\
\hline & & & & Mixed & 3.0 \\
\hline & & & & Malay & 2.8 \\
\hline & & & & Chinese & 1.0 \\
\hline
\end{tabular}

${ }^{+}$using Chinese as a baseline frequency of 1.0.

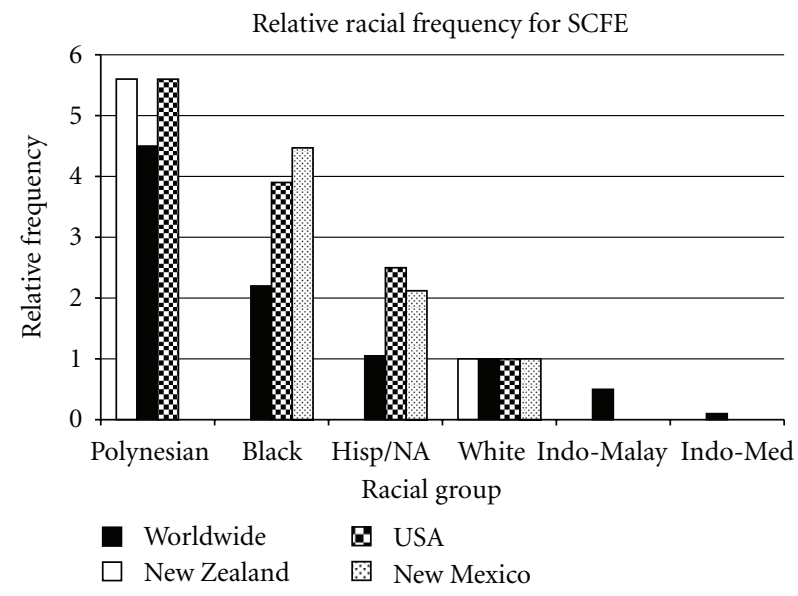

(a)

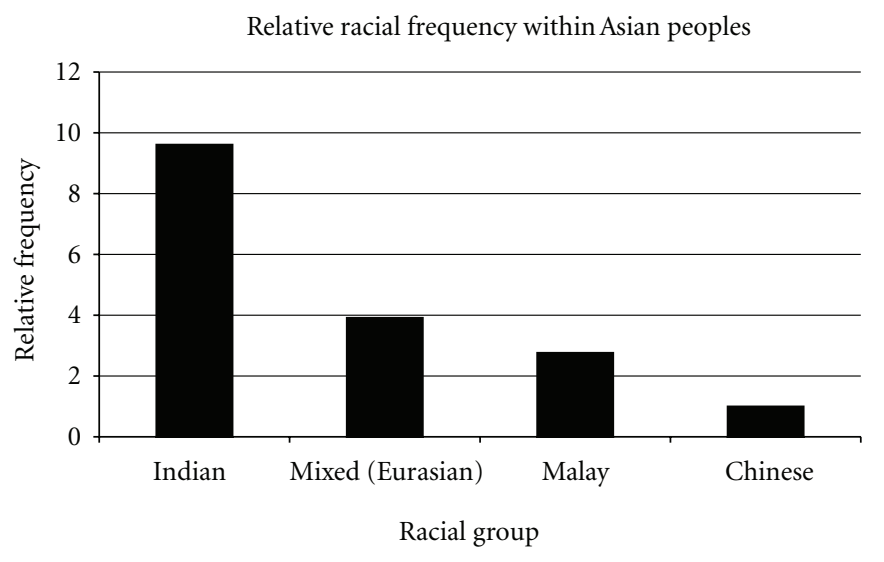

(b)

Figure 3: (a) Relative racial frequencies of SCFE normalized to Caucasian children. The New Zealand data is from [29], worldwide data from Loder [30], USA data from Lehmann et al. [31], and New Mexico data from Benson et al. [32]. (b) Relative racial frequencies of SCFE within the Indo-Malay and Indo-Mediterranean groups, normalized to Chinese children. Data from [33] was used to calculate the relative racial frequencies using previously described methods [30]. 
TABLe 3: Age and gender in 4343 children with SCFE.

\begin{tabular}{|c|c|c|c|c|c|c|c|c|c|c|c|}
\hline Study & Year & City/State/Country & Region & Race & Age & Age-M & Age-F & $\mathrm{M}$ & $\% \mathrm{M}$ & $\mathrm{F}$ & $\% \mathrm{~F}$ \\
\hline \multirow{4}{*}{$\begin{array}{l}\text { Stott and } \\
\text { Bidwell [29] }\end{array}$} & \multirow{4}{*}{2003} & \multirow{4}{*}{$\begin{array}{l}\text { Auckland, New } \\
\text { Zealand }\end{array}$} & \multirow{4}{*}{ Australia/NZ } & All & 11.82 & 12.46 & 11.05 & 115 & 54.5 & 96 & 45.5 \\
\hline & & & & White & 12.33 & 13.00 & 11.59 & 30 & 52.6 & 27 & 47.4 \\
\hline & & & & Maori & 11.51 & 12.18 & 10.69 & 33 & 55.0 & 27 & 45.0 \\
\hline & & & & $\begin{array}{c}\text { Pacific } \\
\text { Islanders }\end{array}$ & 11.65 & 12.24 & 10.92 & 49 & 55.1 & 40 & 44.9 \\
\hline $\begin{array}{l}\text { Noguchi and } \\
\text { Sakamaki [38] }\end{array}$ & 2002 & Japan & Asia & $\begin{array}{l}\text { Indo-Malay } \\
\text { (Japanese) }\end{array}$ & 11.73 & 11.83 & 11.42 & 237 & 75.5 & 77 & 24.5 \\
\hline Jerre et al. [42] & 1996 & $\begin{array}{l}\text { Gothenburg, } \\
\text { Sweden }\end{array}$ & Scandinavia & White & 13.07 & 13.60 & 12.10 & 113 & 64.6 & 62 & 35.4 \\
\hline $\begin{array}{l}\text { Henrikson } \\
{[43]}\end{array}$ & 1969 & $\begin{array}{l}\text { Gothenburg, } \\
\text { Sweden }\end{array}$ & Scandinavia & White & 12.91 & 13.50 & 11.80 & 53 & 65.4 & 28 & 34.6 \\
\hline $\begin{array}{l}\text { Hägglund } \\
\text { et al. [34] }\end{array}$ & 1984 & Southern Sweden & Scandinavia & White & 12.86 & 12.20 & 14.40 & 372 & 69.9 & 160 & 30.1 \\
\hline \multirow{7}{*}{ Loder [30] } & \multirow{7}{*}{1996} & \multirow{7}{*}{ Worldwide } & \multirow{7}{*}{ Worldwide } & White & 12.95 & 13.60 & 12.10 & 435 & 56.7 & 332 & 43.3 \\
\hline & & & & African & 12.88 & 13.80 & 11.70 & 225 & 56.1 & 176 & 43.9 \\
\hline & & & & Amerindian & 12.80 & 13.40 & 11.90 & 164 & 60.3 & 108 & 39.7 \\
\hline & & & & Indo-Malay & 12.09 & 12.30 & 11.50 & 89 & 74.2 & 31 & 25.8 \\
\hline & & & & NA/PI & 11.85 & 12.00 & 11.70 & 17 & 50.0 & 17 & 50.0 \\
\hline & & & & Indo-Med & 12.99 & 13.20 & 11.00 & 19 & 90.5 & 2 & 9.5 \\
\hline & & & & All & 12.88 & 13.50 & 12.00 & 959 & 58.8 & 671 & 41.2 \\
\hline $\begin{array}{l}\text { Aronson and } \\
\text { Loder [45] }\end{array}$ & 1992 & Detroit, Michigan & $\begin{array}{l}\text { North } \\
\text { America }\end{array}$ & African & 12.53 & 13.42 & 11.08 & 46 & 62.2 & 28 & 37.8 \\
\hline $\begin{array}{l}\text { Ninomiya } \\
\text { et al. [36] }\end{array}$ & 1976 & Eastern Japan & Asia & $\begin{array}{l}\text { Indo-Malay } \\
\text { (Japanese) }\end{array}$ & 12.49 & 12.75 & 11.00 & 58 & 85.3 & 10 & 14.7 \\
\hline $\begin{array}{l}\text { Loder et al. } \\
\text { [46] }\end{array}$ & 2006 & $\begin{array}{l}\text { Michigan and } \\
\text { Indiana }\end{array}$ & $\begin{array}{c}\text { North } \\
\text { America }\end{array}$ & All & 12.60 & & & 159 & 65.4 & 84 & 34.6 \\
\hline Lim et al. [33] & 2008 & Singapore & Asia & All & 12.20 & 12.40 & 11.10 & 53 & 80.3 & 13 & 19.7 \\
\hline $\begin{array}{l}\text { Bosch et al. } \\
\text { [32] }\end{array}$ & 2008 & New Mexico & $\begin{array}{c}\text { North } \\
\text { America }\end{array}$ & All & 12.20 & 12.50 & 11.50 & & & & \\
\hline Burrows [47] & 1957 & London, England & Europe & & 14.70 & 16.53 & 11.95 & 60 & 60.0 & 40 & 40.0 \\
\hline $\begin{array}{l}\text { Carlioz et al. } \\
\text { [48] }\end{array}$ & 1984 & Paris, France & Europe & & 13.19 & 14.00 & 12.50 & 31 & 46.3 & 36 & 53.7 \\
\hline $\begin{array}{l}\text { Aronson and } \\
\text { Carlson [13] }\end{array}$ & 1992 & Detroit, Michigan & $\begin{array}{c}\text { North } \\
\text { America }\end{array}$ & All & & & & 31 & 70.5 & 13 & 29.5 \\
\hline $\begin{array}{l}\text { Aronson et al. } \\
\text { [49] }\end{array}$ & 1992 & Detroit, Michigan & $\begin{array}{c}\text { North } \\
\text { America }\end{array}$ & All & 12.85 & 13.50 & 11.70 & 35 & 63.6 & 20 & 36.4 \\
\hline $\begin{array}{l}\text { Carney et al. } \\
{[26]}\end{array}$ & 1991 & Iowa & $\begin{array}{c}\text { North } \\
\text { America }\end{array}$ & & 12.98 & 13.40 & 11.30 & 99 & 79.8 & 25 & 20.2 \\
\hline $\begin{array}{l}\text { Dreghorn } \\
\text { et al. [50] }\end{array}$ & 1987 & Glasgow, Scotland & Europe & & 12.98 & 13.50 & 12.25 & 45 & 58.4 & 32 & 41.6 \\
\hline $\begin{array}{l}\text { Kulick and } \\
\text { Denton [51] }\end{array}$ & 1982 & New York & $\begin{array}{c}\text { North } \\
\text { America }\end{array}$ & All & 12.62 & 13.00 & 12.00 & 58 & 61.7 & 36 & 38.3 \\
\hline $\begin{array}{l}\text { Weiner et al. } \\
{[35]}\end{array}$ & 1984 & Akron, Ohio & $\begin{array}{l}\text { North } \\
\text { America }\end{array}$ & All & 13.05 & 13.40 & 12.20 & 113 & 71.1 & 46 & 28.9 \\
\hline $\begin{array}{l}\text { Koval et al. } \\
\text { [52] }\end{array}$ & 1989 & New York & $\begin{array}{l}\text { North } \\
\text { America }\end{array}$ & All & 12.10 & & & 37 & 61.7 & 23 & 38.3 \\
\hline $\begin{array}{l}\text { Song et al. } \\
{[44]}\end{array}$ & 2009 & & South Korea & Indo-Malay & 12.67 & 12.83 & 12.00 & 175 & 75.8 & 56 & 24.2 \\
\hline Averages & & & & & 11.96 & 12.05 & 11.21 & 2806 & 64.3 & 1556 & 35.7 \\
\hline
\end{tabular}

The averages are weighted to account for the number of children in each series. The overall age was used in those series where ages are given by ethnicity [29, 30]. 


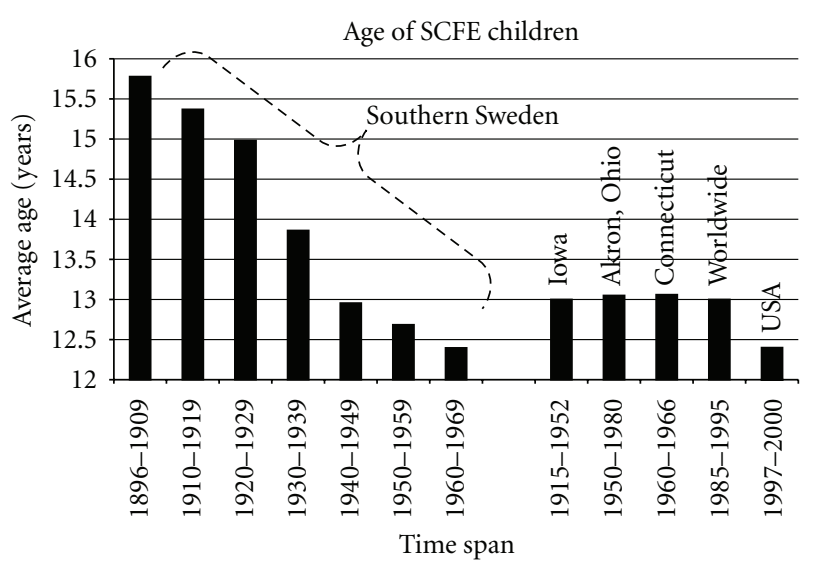

(a)

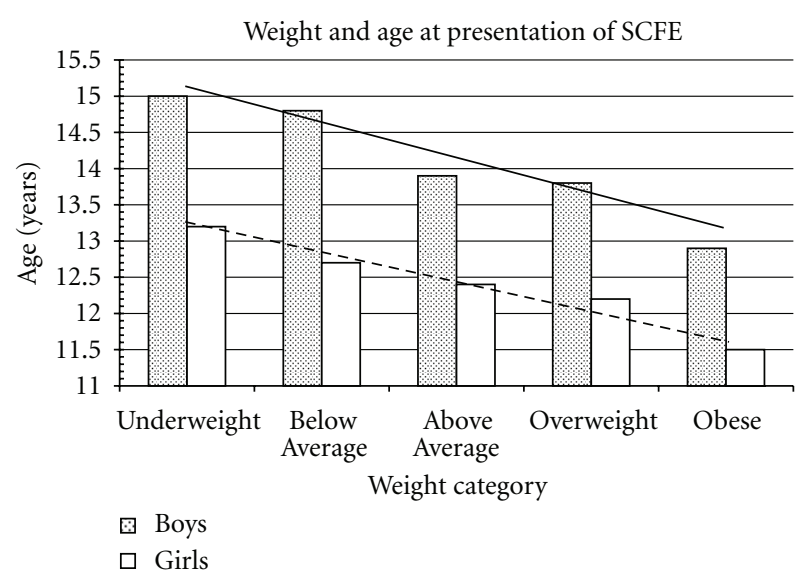

(b)

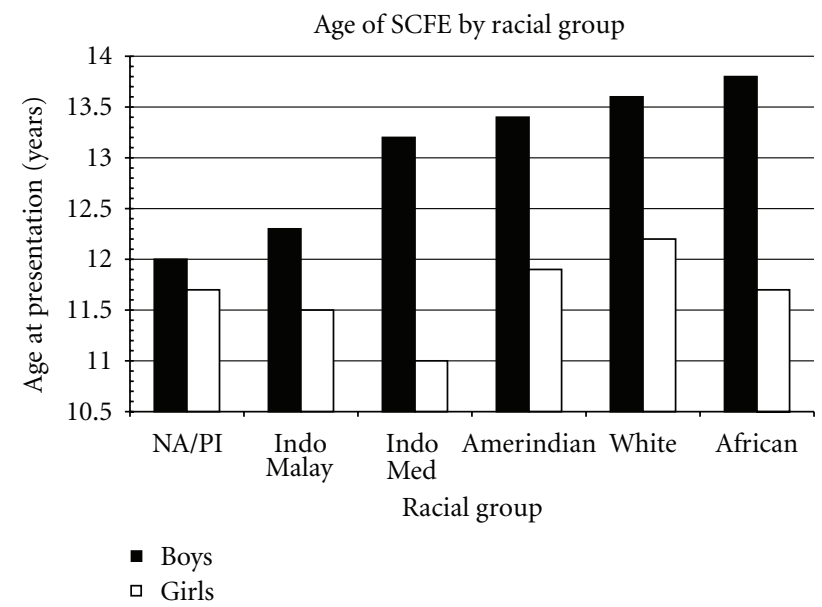

(c)

Figure 4: (a) The changing age at diagnosis of children with SCFE over the last century. The southern Sweden data is from [34]; the Iowa data is from [26]; the Akron, Ohio data is from [35]; the worldwide data is from Loder [30]; the USA data from Lehmann et al. [31]. (b) The average age at presentation of children with SCFE by weight category for both girls and boys. The average age follows a linear with the weight category (WC) for both the boys (solid black line) (age $\left.=12.5-0.52 \mathrm{WC}, r^{2}=0.94, P=0.006\right)$ and girls (hatched black line) (age $=$ 11.2-0.39 WC, $r^{2}=0.96, P=0.003$ ) $\{$ WC of $5=$ obese class, WC of $4=$ overweight class, WC of $3=$ above average class, WC of $2=$ below average class, and WC of $1=$ underweight class\}. Data from Loder [30]. (c) The average age by racial group for girls and boys with SCFE. NA/PI: Native Australian/Polynesian, data from Loder [30].

12.0 years for girls [30] and is now 12.0 years for boys and 11.2 years for girls (Table 3). In Scotland, the age has dropped from 13.4 to 12.6 years over a 20-year period [40]. These younger ages reflect the earlier maturation of today's children [31]. Obese children present earlier than nonobese children (Figure 4(b)). One study demonstrated different ages at presentation by racial group (Figure 4(c)) [30]. The physiologic age range during which SCFE occurs is less variable than the chronologic age range (Figure 5), termed the "narrow window" [56, 63].

3.4. Symptom Duration. The average symptom duration for stable SCFEs is 4 to 5 months (with minimal difference by gender). In 2482 children, the average symptom duration was 4.3 months; 4.5 months for boys and 3.6 months for girls (Table 4). Two recent studies have noted a decrease in symptom duration to $2-3$ months $[46,88]$.

Although there is a general correlation between symptom duration and SCFE severity [88] there is considerable variability (Figure 6(a)) [46]. For any given individual child, slip severity and symptom duration is unique; in a large population, there is a weak positive correlation with slip severity and symptom duration. Mild SCFEs have a shorter duration of symptoms than severe SCFEs (Figure 6(b)) which suggests that all SCFEs start at a similar age; those children with severe SCFEs just had a longer symptom duration and time to presentation than those with milder SCFEs. In a review of 328 stable SCFEs this was documented; a child with a stable SCFE was 2.0 times more likely to have a moderate or severe SCFE if $>$ than 12.5 years at diagnosis 


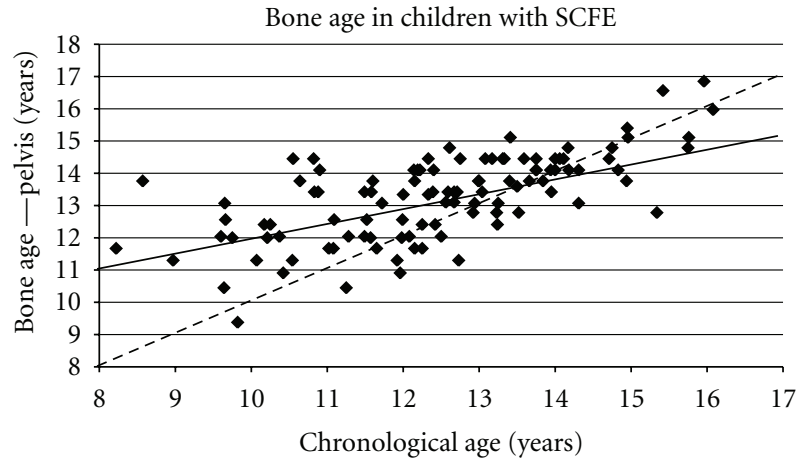

FIgURE 5: The pelvis bone age (Oxford score converted into years) as a function of chronologic age in 108 children with SCFE. The observed pelvis bone age is represented by the solid line, and is represented by the equation Pelvis Bone Age $=6.95+0.51$ (Chronologic Age), $r^{2}=0.47, P<10^{-6}$. The dotted line represents what would be found if the pelvis bone age and chronologic age were the same. The slope of the linear correlation for the actual pelvis bone age, 0.51 , is $1 / 2$ that if the bone and chronologic ages were equal, supporting the concept of the narrow bone age window for proximal epiphyseal slipping, data from Loder et al. [56].

than if $<12.5$ years at diagnosis, and a child with a stable SCFE is 4.1 times more likely to have a moderate or severe SCFE if the duration of symptoms is $>$ than 2 months than if $\leq 2$ months [46]. Other positive predictors of increasing time to diagnosis are knee/distal thigh pain, Medicaid coverage, lower family income, and a stable SCFE [88].

Slip severity and symptom duration is greater in children presenting with knee pain compared to other symptoms [88-91]. In a study of 45 children [89], 15 presented solely with knee pain having an average symptom duration of 8.3 months; $74 \%$ of the SCFEs were severe. The remaining 30 presented with other symptoms with an average symptom duration of 6.5 months; $24 \%$ of the SCFEs were severe. Rahme et al. [90] reviewed 87 children with stable SCFEs, 20 had a delayed diagnosis, with $8(40 \%)$ being severe. In Leeds, England, those children with SCFE diagnosed in the emergency department compared to general practitioners had a shorter symptom duration (95 versus 119 days) and fewer severe SCFEs ( 8 versus 21\%). One study, however, did not see a difference in symptom duration in SCFE children where the diagnosis had been initially missed due to the absence of hip pain (average symptom duration 127 days and 146 days in those whose diagnosis was and was not missed) [92].

It would seem reasonable that as symptom duration increases radiographic changes should concomitantly progress (more metaphyseal remodeling). The presence or absence of a positive Klein line and metaphyseal remodeling (superior and anterior smoothing, inferior and posterior buttressing) were directly correlated to symptom duration but with significant variability [93]. Those with more metaphyseal changes had higher BMIs, interpreted as the larger body mass per unit height resulting in more bony reaction/adaptation according to Wolf's law.

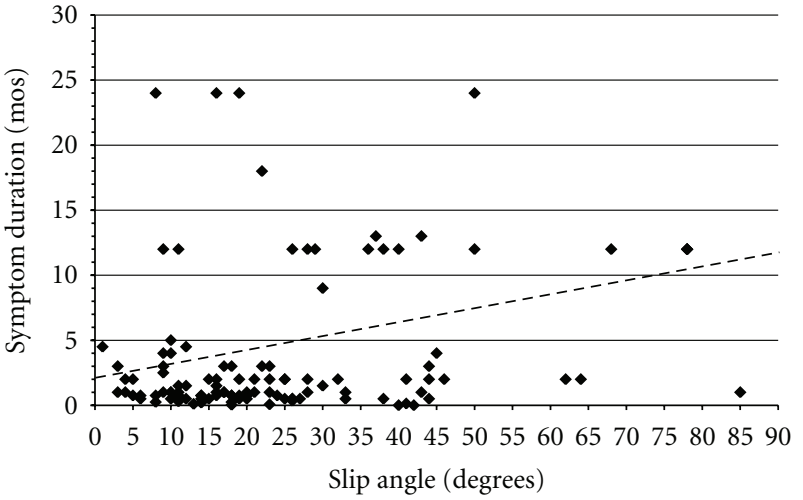

(a)

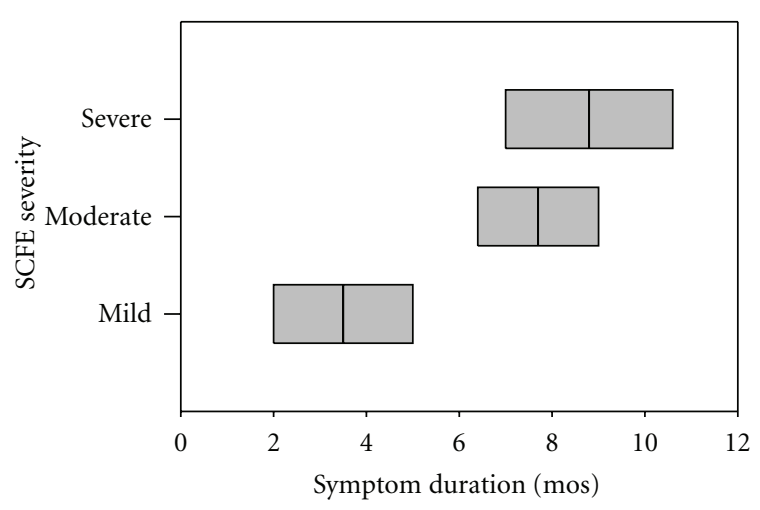

(b)

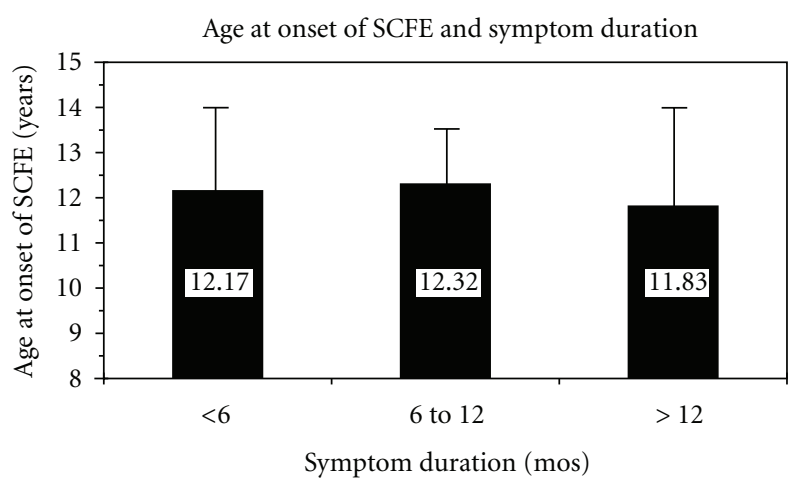

(c)

Figure 6: (a) Symptom duration as a function of slip severity (lateral epiphyseal shaft angle) in 254 stable SCFEs. The best fit line is represented by the dotted line: symptom duration $=2.16+$ 0.106 (slip angle), $\left(P<0.0001, r^{2}=0.084\right)$, where the slip angle is expressed in degrees and the symptom duration in months. Data from Loder et al. [46]. (b) Average symptom duration in months (middle black line in the gray box) \pm one standard deviation (entire gray box) for mild, moderate, and severe stable SCFEs, data from Loder et al. [46]. (c) Categories of symptom duration in months (solid column) + one standard deviation (error bar) and age at onset of the SCFE defined as age at diagnosis minus symptom duration. There was no statistically significant difference in the age at onset for those children with different categories of symptom duration $\left(\mathrm{ANOVA}_{2,258}, F=0.56, P=0.57\right)$, indicating a small age window at which the SCFE begins. The average age for each symptom duration group is noted, data from Loder et al. [46]. 
TABLE 4: Symptom duration in 2482 children with SCFE.

\begin{tabular}{|c|c|c|c|c|c|c|c|c|}
\hline Study & Year & City/State/Country & Region & $\begin{array}{c}\text { Number of } \\
\text { Patients }\end{array}$ & Race & $\begin{array}{l}\text { Sx Dur } \\
\text { Males }\end{array}$ & $\begin{array}{l}\text { Sx Dur } \\
\text { Females }\end{array}$ & $\begin{array}{c}\text { Sx Dur } \\
\text { Combined }\end{array}$ \\
\hline $\begin{array}{l}\text { Hägglund } \\
\text { et al. [34] }\end{array}$ & 1984 & Southern Sweden & Scandinavia & 532 & White & 4.8 & 3.4 & 4.4 \\
\hline \multirow{7}{*}{ Loder [30] } & \multirow{7}{*}{1996} & \multirow{7}{*}{ Worldwide } & \multirow{7}{*}{ Worldwide } & 767 & White & 4.1 & 3.8 & 4.0 \\
\hline & & & & 401 & African & 4.9 & 3.6 & 4.3 \\
\hline & & & & 272 & Amerindian & 4.3 & 3.8 & 4.1 \\
\hline & & & & 120 & Indo-Malay & 5.1 & 5.5 & 5.2 \\
\hline & & & & 34 & NA/PI & 2.4 & 2.5 & 2.5 \\
\hline & & & & 21 & Indo-Med & 3.7 & 6.25 & 3.9 \\
\hline & & & & 1630 & All & 4.4 & 3.7 & 4.1 \\
\hline $\begin{array}{l}\text { Loder et al. } \\
{[46]}\end{array}$ & 2006 & $\begin{array}{l}\text { Michigan and } \\
\text { Indiana }\end{array}$ & $\begin{array}{c}\text { North } \\
\text { America }\end{array}$ & 243 & All & & & 5.2 \\
\hline$[50]$ & 1987 & Glasgow, Scotland & Europe & 77 & All & & & 3.8 \\
\hline Totals & & & & 2482 & & 4.5 & 3.6 & 4.3 \\
\hline
\end{tabular}

The symptom duration averages are weighted to account for the number of children in each series. The overall symptom duration was used in the series where symptom duration is given by ethnicity [30].

The age at diagnosis of the 1st SCFE correlates with SCFE severity and is also related to the narrow physiologic window $[56,63]$. Subtracting the average symptom duration for the mild, moderate, and severe categories from the average age at presentation results in a similar average age at onset (Figure 6(c)), confirming the narrow bone age window.

3.5. Body Weight, Obesity, and BMI. The majority of children are obese; $>50 \%$ of children with SCFE are $>95$ th percentile weight for age [30, 94-96]. Age at diagnosis decreases with increasing obesity [30]; 12.4 years for those over the 95th percentile weight for age and 14.3 years for those under the 10th percentile weight for age. Recently body mass index (BMI) $[97,98]$ has been used to evaluate body habitus; the average BMI in SCFE children is $25-30 \mathrm{~kg} / \mathrm{m}^{2}$ or $>85$ th percentile [39, 46, 99-102]. The average BMI of children with bilateral SCFE is higher than with unilateral SCFE (26.8 versus $31.1 \mathrm{~kg} / \mathrm{m}^{2}$ ) [99].

Obese children have decreased femoral anteversion, and SCFE children have femoral retroversion even in the noninvolved hip $[103,104]$. This, along with biomechanical studies demonstrating an increased physeal stress in retroverted hips and the many demographic studies associating obesity with SCFE, supports the theory that obesity is intimately involved in the development of most idiopathic SCFEs [105].

3.6. Seasonal Variation. In latitudes north of $40^{\circ}$ SCFE presents more frequently in the late summer and autumn months (Figure 7(a)) [34, 58, 59, 61, 62, 106, 107]. Subtracting symptom duration from the time of presentation demonstrates that the SCFE onset is in the early summer/late spring months (Figure 7(b)).

3.7. Bilaterality. The reported proportion of bilaterality depends upon the study, method of radiographic measurement, race, and treatment (Table 5). Most series report 18 to $50 \%$ bilaterality [30] with recent follow-up studies into adulthood quoting 63\% [34, 109, 110] and 66\% [111]. Bilaterality is more frequent in Africans (34\%) than Hispanics (17\%), Whites (17\%), or Asians (18\%) [30]. Treatment may affect risk of bilaterality; bilaterality is 36\% with in situ fixation and 7\% spica cast treatment [112]. Close attention is mandatory to the opposite normal hip in those children with a unilateral SCFE treated by in situ fixation.

The age at presentation is younger in children who present with a unilateral SCFE that later develops bilateral SCFEs compared to those who do not develop bilateral SCFEs $[17,50,59,113-116]$. This age difference is seen in both chronologic age (12 versus 13 years of age) $[17,30,115$, $116]$ and bone age. In one study the overall difference in chronologic age in those with a unilateral SCFE that became bilateral compared to those that stayed unilateral was 1 year (12 versus 13 years) [17]; in another study 0.9 years for girls (11.0 versus 11.9 years) and 2.2 years (12.1 versus 14.2 years) for boys [115]; and in a 3rd study 11.5 versus 12.7 years, with those children aging $<12$ years having a unilateral SCFE demonstrated a 3.8 times increased risk of developing a contralateral SCFE [116]. In a study of 50 children with unilateral SCFE [113] using a modified Oxford hip bone age, a contralateral SCFE occurred in $85 \%$ of hips having a score of $16,11 \%$ of hips having a score of 21 , and never when the score was $\geq 22$. Once the triradiate cartilage has closed, the risk of a contralateral SCFE is only $4 \%$ [117], although another study did not find any association between the status of the triradiate cartilage, other skeletal maturity markers, and subsequent bilaterality [118]. The risk of bilaterality is increased when the posterior slope angle of the capital femoral epiphysis is higher $[119,120]$.

In children with bilateral SCFEs, $50-60 \%$ present with simultaneous bilateral involvement. In those children with sequential bilateral SCFEs, $80-90 \%$ of the second SCFEs occur within the first 18 months after the first SCFE (Figure 8) [17, 29, 30, 34, 50, 67, 102, 121, 122]. In unilateral SCFEs, $60 \%$ involve the left hip. 


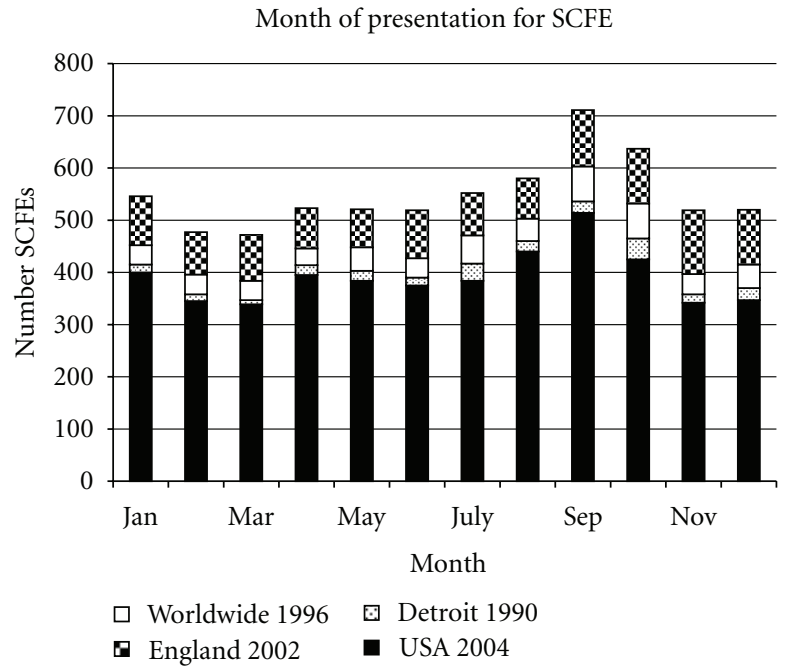

(a)

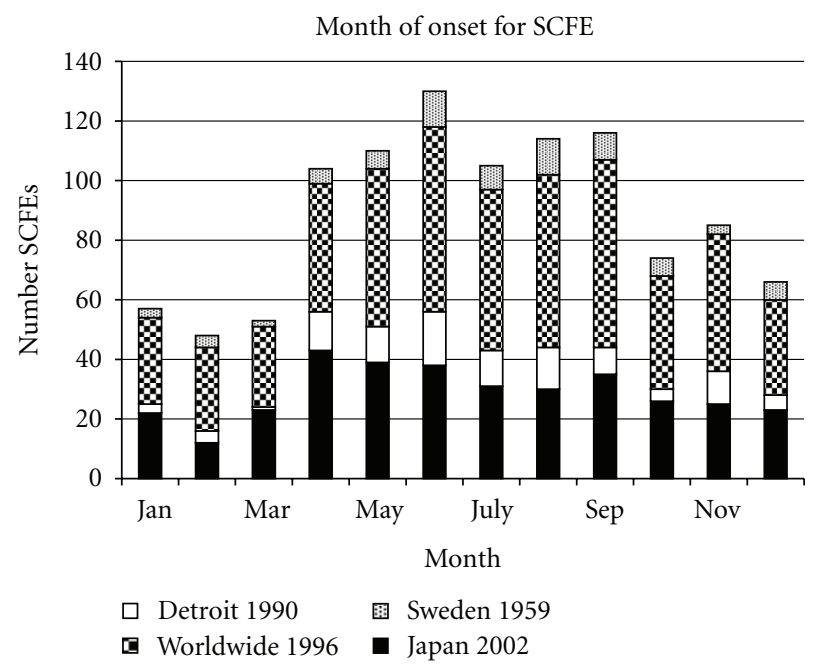

(b)

FIGURE 7: (a) Seasonal variation in the month of presentation of children with SCFE when north of the $40^{\circ}$ North latitude. The data for England 2002 are from Maffulli and Douglas [58], worldwide 1996 from Loder [59], Detroit 1990 from Loder et al. [60], and USA 2004 from Brown [61]. Note the peak in September and October. (b) Seasonal variation in the month of onset of children with SCFE when north of the $40^{\circ}$ North latitude. The data for Sweden 1959 are from Andrén and Borgström [62], worldwide 1996 from Loder [59], Detroit 1990 from Loder et al. [60], and Japan 2002 from Noguchi and Sakamaki [38]. Note the peak in June, 3 to 4 months before the peak for presentation in (a).

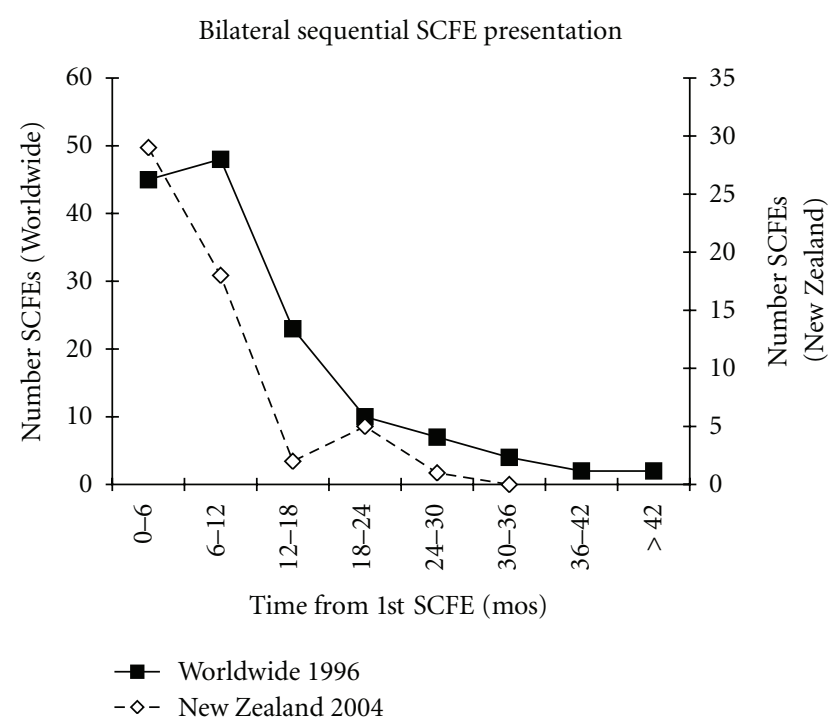

FIGURE 8: The time between the diagnosis of the 1st and 2nd SCFE of children with sequential bilateral SCFEs. The number of bilateral SCFEs for every 6 month time period from the time of the 1st SCFE is shown. The worldwide data are from Loder [30], and New Zealand data from Stott and Bidwell [29].

3.8. Predictors of Idiopathic and Atypical SCFEs. Tests for a disease are evaluated in terms of sensitivity, specificity, positive predictive value, and negative predictive value [123]. Sensitivity is the proportion of individuals in a tested population who actually have the disease and are identified as having it with the test. Specificity is the proportion of individuals in a tested population who do not have a given disease and are identified as not having it with the test. Sensitivity is increased at the expense of specificity. The probability that a person with a positive result truly has the disease is the positive predictive value; the probability that a person with a negative test truly does not have the disease is the negative predictive value. When evaluating a child with a newly diagnosed SCFE, the underlying etiology immediately comes into consideration. This is for both diagnostic concerns with potential medical issues as well as orthopaedic treatment. The underlying medical issues involve significant anesthetic concerns [108]; treatment involves the question of prophylactic fixation of the opposite hip when the child presents with a unilateral SCFE. Any "test" that can give an accurate negative predictive value for a child with a SCFE not having an atypical SCFE is important. If the test has a high negative predictive value, the clinician can be confident that the SCFE is idiopathic. If the test is positive, further diagnostic investigation should be strongly considered.

Atypical SCFEs are those associated with endocrine/renal disorders or prior radiation therapy. The history of prior radiation therapy is usually discovered in the initial evaluation. However, many times it is the orthopaedic surgeon who picks up on an underlying medical problem as the etiology of the SCFE (e.g. endocrine dysfunction, renal osteodystrophy). In 2001 the age-weight test [108] was described to assist in the differentiation between an idiopathic and atypical SCFE. The age-weight test is defined as negative when age $<16$ years and weight $\geq 50$ th percentile and positive when beyond these boundaries (Table 6). The "disease" is the child having an 
TABLE 5: Laterality in 3037 children with SCFE.

\begin{tabular}{|c|c|c|c|c|c|c|c|c|c|c|c|c|}
\hline Study & Year & City/State/Country & Region & Race & $\mathrm{U}$ & $\% \mathrm{U}$ & $\mathrm{B}$ & $\% \mathrm{~B}$ & $\mathrm{R}$ & $\% \mathrm{R}$ & $\mathrm{L}$ & $\% \mathrm{~L}$ \\
\hline \multirow{4}{*}{$\begin{array}{l}\text { Stott and } \\
\text { Bidwell [29] }\end{array}$} & \multirow{4}{*}{2003} & \multirow{4}{*}{$\begin{array}{c}\text { Auckland, New } \\
\text { Zealand }\end{array}$} & \multirow{4}{*}{ Australia/NZ } & All & 64 & 55.7 & 51 & 44.3 & 22 & 34.4 & 42 & 65.6 \\
\hline & & & & White & 28 & 49.1 & 29 & 50.9 & 10 & 35.7 & 18 & 64.3 \\
\hline & & & & Maori & 36 & 60.0 & 24 & 40.0 & 8 & 22.2 & 28 & 77.8 \\
\hline & & & & $\begin{array}{c}\text { Pacific } \\
\text { Islanders }\end{array}$ & 47 & 52.8 & 42 & 47.2 & 18 & 38.3 & 29 & 61.7 \\
\hline $\begin{array}{l}\text { Noguchi and } \\
\text { Sakamaki } \\
{[38]}\end{array}$ & 2002 & Japan & Asia & $\begin{array}{c}\text { Indo-Malay } \\
\text { (Japanese) }\end{array}$ & 270 & 86.0 & 44 & 14.0 & 127 & 47.0 & 143 & 53.0 \\
\hline $\begin{array}{l}\text { Jerre et al. } \\
{[42]}\end{array}$ & 1996 & $\begin{array}{l}\text { Gothenburg, } \\
\text { Sweden }\end{array}$ & Scandinavia & White & 173 & 98.9 & 2 & 1.1 & 69 & 39.9 & 104 & 60.1 \\
\hline $\begin{array}{l}\text { Hägglund } \\
\text { et al. [34] }\end{array}$ & 1984 & Southern Sweden & Scandinavia & White & 451 & 84.8 & 81 & 15.2 & 171 & 33.5 & 339 & 66.5 \\
\hline \multirow{7}{*}{ Loder [30] } & \multirow{7}{*}{1996} & \multirow{7}{*}{ Worldwide } & \multirow{7}{*}{ Worldwide } & White & 663 & 83.2 & 134 & 16.8 & 239 & 37.8 & 394 & 62.2 \\
\hline & & & & African & 264 & 65.8 & 137 & 34.2 & 109 & 41.3 & 155 & 58.7 \\
\hline & & & & Amerindian & 227 & 83.5 & 45 & 16.5 & 96 & 42.5 & 130 & 57.5 \\
\hline & & & & Indo-Malay & 98 & 81.7 & 22 & 18.3 & 49 & 50.0 & 49 & 50.0 \\
\hline & & & & NA/PI & 21 & 61.8 & 13 & 38.2 & 8 & 38.1 & 13 & 61.9 \\
\hline & & & & Indo-Med & 13 & 61.9 & 8 & 38.1 & 5 & 38.5 & 8 & 61.5 \\
\hline & & & & All & 1267 & 77.7 & 363 & 22.3 & 510 & 40.3 & 756 & 59.7 \\
\hline $\begin{array}{l}\text { Loder et al. } \\
{[46]}\end{array}$ & 2006 & $\begin{array}{l}\text { Michigan and } \\
\text { India }\end{array}$ & North America & All & 149 & 61.3 & 94 & 38.7 & 63 & 42.3 & 86 & 57.7 \\
\hline $\begin{array}{l}\text { Lim et al. } \\
{[33]}\end{array}$ & 2008 & Singapore & Asia & All & 42 & 79.2 & 11 & 20.8 & 25 & 45.5 & 30 & 54.5 \\
\hline Burrows [47] & 1957 & London, England & Europe & & 77 & 77.0 & 23 & 23.0 & 29 & 37.7 & 48 & 62.3 \\
\hline $\begin{array}{l}\text { Carlioz et al. } \\
{[48]}\end{array}$ & 1984 & Paris, France & Europe & & 54 & 80.6 & 13 & 19.4 & 22 & 40.7 & 32 & 59.3 \\
\hline $\begin{array}{l}\text { Aronson and } \\
\text { Carlson [13] }\end{array}$ & 1992 & Detroit, Michigan & North America & All & 30 & 68.2 & 14 & 31.8 & & & & \\
\hline $\begin{array}{l}\text { Aronson } \\
\text { et al. [49] }\end{array}$ & 1992 & Detroit, Michigan & North America & All & 30 & 54.5 & 25 & 45.5 & & & & \\
\hline $\begin{array}{l}\text { Carney et al. } \\
{[26]}\end{array}$ & 1991 & Iowa & North America & & 93 & 75.0 & 31 & 25.0 & & & & \\
\hline $\begin{array}{l}\text { Dreghorn } \\
\text { et al.[50] }\end{array}$ & 1987 & Glasgow, Scotland & Europe & & 58 & 75.3 & 19 & 24.7 & & & & \\
\hline $\begin{array}{l}\text { Kulick and } \\
\text { Denton [51] }\end{array}$ & 1982 & New York & North America & All & 63 & 67.0 & 31 & 33.0 & & & & \\
\hline $\begin{array}{l}\text { Koval et al. } \\
{[52]}\end{array}$ & 1989 & New York & North America & All & 29 & 59.2 & 20 & 40.8 & 36 & 45.0 & 44 & 55.0 \\
\hline $\begin{array}{l}\text { Song et al. } \\
{[44]}\end{array}$ & 2009 & & South Korea & Indo-Malay & 187 & 81.0 & 44 & 19.0 & 77 & 41.2 & 110 & 58.8 \\
\hline Totals & & & & & 3037 & 77.8 & 866 & 22.2 & 1151 & 39.9 & 1734 & 60.1 \\
\hline
\end{tabular}

TABLE 6: The age-weight or age-height test in children with SCFE is determined by graphically visualizing 6 groupings (or "cells") of children with SCFE: cell $1,<10$ years of age and $\geq 50$ th percentile in weight/height; cell $2, \geq 10, \leq 16$ years of age and $\geq 50$ th percentile in weight/height; cell $3,>16$ years of age and $\geq 50$ th percentile in weight/height; cell $4,<10$ years of age and $<50$ th percentile in weight/height; cell $5, \geq 10$, $\leq 16$ years of age and $<50$ th percentile in weight/height; and cell $6,>16$ years of age and $<50$ th percentile weight/height. Children in cells $3-6$ (bold print) are considered to have a positive age-weight or age-height test; children in cells 1 and 2 (italic calligraphy) are considered to have a negative age-weight or age-height test.

\begin{tabular}{|c|c|c|c|}
\hline \multirow{2}{*}{ Weight or height percentile } & \multicolumn{3}{|c|}{ Age of patient with SCFE } \\
\hline & $<10$ years & $10-16$ years & $>16$ years \\
\hline$\geq 50$ th & Cell 1 (- test) & Cell 2 (- test) & CELL 3 (+ TEST) \\
\hline$<50$ th & CELL 4 (+ TEST) & CELL 5 (+ TEST) & CELL 6 (+ TEST) \\
\hline
\end{tabular}




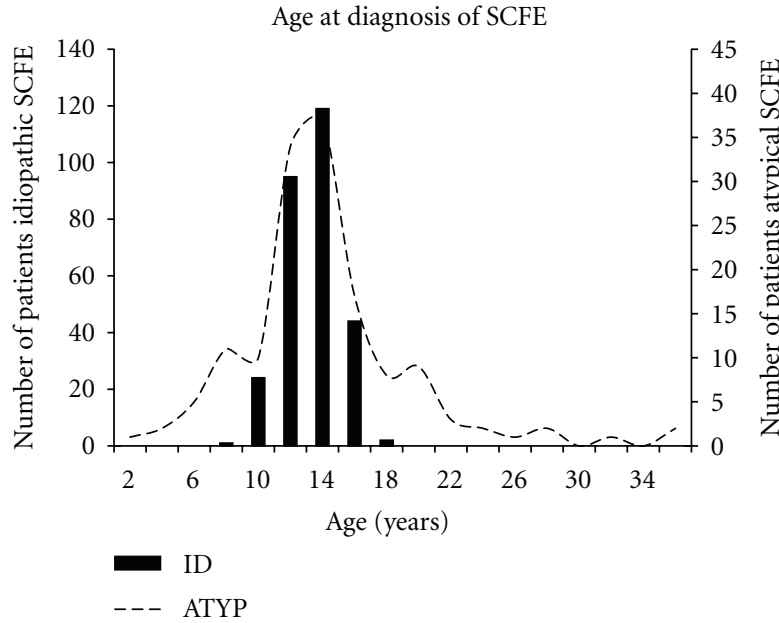

(a)
Bilaterality of SCFE

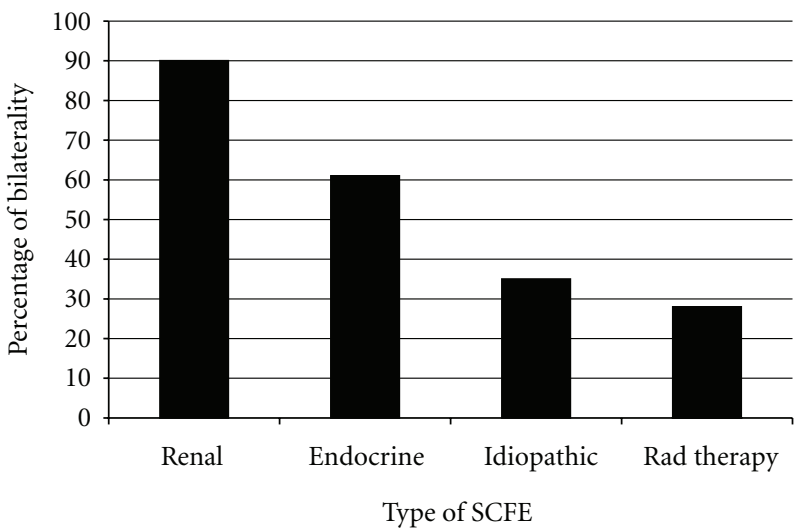

(b)

Figure 9: (a) A histogram showing the age at diagnosis of SCFE. Note the narrow age range for children with idiopathic SCFE (92\% 10-16 years of age), with a broader range for children with atypical SCFEs (those associated with renal failure, radiation therapy, or endocrinopathy). Data from the study of Loder and Greenfield [108]. (b) Frequency of bilaterality amongst different types of SCFE, data from Loder and Greenfield [108].

atypical SCFE, absence of "disease" is the child having an idiopathic SCFE. The demographics of 433 children $(285$ idiopathic, 148 atypical) with 612 SCFEs were studied to define predictors of atypical SCFEs. There was significant variability in both age and bilaterality between the atypical and idiopathic groups (Figure 9). Multiple logistic regression analysis demonstrated that age and weight were predictors of an atypical SCFE. For two patients of equal weight, those $<10$, or $>16$ years of age are 4.2 times more likely to have an atypical SCFE; for two patients of equal age, those $<50$ th percentile weight are 8.4 times more likely. The probability of a child with a negative test having an idiopathic SCFE is 93\%, and a child with positive test having an atypical SCFE is 52\%. In the same year the age-weight test was described for all atypical SCFEs, Burrow et al. [124] showed that the height at diagnosis was an important predictor of an endocrinopathy. The sensitivity and negative predictive value of detecting an underlying endocrinopathy in a patient with a SCFE who was $<10$ th percentile in height for age were $90.2 \%$ and $98 \%$.

The age-weight test was further confirmed in 2006, along with the definition of the height and age-height tests [125]. The age-height test was defined using the same cells as the age-weight test except that the percentiles applied to height rather than weight. This test has a positive and negative predictive value of $30 \%$ and $98 \%$. The height test is defined as positive if the child's height is $\leq 10$ th percentile and negative if $>10$ th percentile for age. It is the same test described by Burrow et al. [124] amplified to include all atypical SCFEs, not just those associated with an endocrinopathy. The height test has a positive and negative predictive value of $75 \%$ and $97 \%$.

Of these three tests, all have similar negative predictive values (93 to $98 \%$ ). The height test has the best positive predictive value $(75 \%)$. The height test is likely to be the most useful in the differentiation between a typical and atypical SCFE if the height of a child can be obtained. When the height cannot be obtained, the age weight test will result in a similar negative predictive value but with a lower positive predictive value. Thus the weight, and where possible, the height of any child newly diagnosed with a SCFE should be obtained to assist in the differentiation between an atypical and idiopathic SCFE.

3.9. Inheritance and Genetics. Little is known regarding the heredity and genetics of SCFE. Familial SCFE was first noted in the English language literature in 1940 [64] with many more subsequent descriptions [65-74, 76-80, 83-87]. Proposed patterns of genetic transmission include X-linked dominant, autosomal dominant with variable penetrance, and autosomal recessive $[68,71,73,77]$. HLA phenotype studies in children demonstrate no common findings (Table 7) [74, 75, 79-82, 86].

\subsection{Miscellaneous Associations/Findings}

Other Skeletal Abnormalities. In most children with SCFE, femoral anteversion is decreased. In a 3-dimensional CT scan study of 30 SCFEs [126] there was a reduction in femoral anteversion from $12.7^{\circ}$ to $7.0^{\circ}$ as well as a reduction in the femoral neck shaft angle from $141^{\circ}$ to $134^{\circ}$. In another CT scan study of 25 SCFEs [103] a reduction of femoral version $1^{\circ}$ was noted in the involved hip and $7^{\circ}$ in the uninvolved hip in unilateral cases. In a 3rd CT scan study of 25 SCFEs [127] femoral anteversion was $9.8^{\circ}$ and $25^{\circ}$ in a control group of children between the ages of 8 and 16 years. Reduced femoral anteversion in obese adolescents is well known [104]. Patients with acute SCFEs have less reduction 
TABLe 7: Familial and genetic studies of SCFE.

\begin{tabular}{|c|c|c|c|c|c|c|}
\hline Study & Year & Type of series & Number of cases & $\begin{array}{l}\% \text { familial } \\
\text { incidence }\end{array}$ & $\begin{array}{l}\text { Postulated } \\
\text { inheritance }\end{array}$ & HLA Phenotype \\
\hline Thrap-Meyer [64] & 1940 & Case report & Father and son & - & - & - \\
\hline Irwin [65] & 1946 & Case report & Father and 2 twin sons & - & - & - \\
\hline Smith [66] & 1955 & Case report & 2 brothers & - & - & - \\
\hline Wilson et al. [67] & 1965 & Case series & 12 of 240 cases & $5 \%$ & - & - \\
\hline Rennie [68] & 1967 & Case reports & $\begin{array}{l}12 \text { children, } 8 \text { different } \\
\text { families }\end{array}$ & $7 \%$ & $\begin{array}{l}\text { Recessive with low } \\
\text { penetrance }\end{array}$ & - \\
\hline Ochsner et al. [69] & 1977 & Case report & 10 members of one family & - & $\begin{array}{c}\text { Autosomal } \\
\text { dominant with } \\
\text { variable penetrance }\end{array}$ & - \\
\hline Gorin $[70]$ & 1977 & Case report & Identical twins & - & - & \\
\hline Rennie [71] & 1982 & $\begin{array}{l}\text { Retrospective } \\
\text { review }\end{array}$ & 214 & $\begin{array}{c}14.5 \% \\
18.8 \% \text { for } \\
\text { osteoarthritis }\end{array}$ & $\begin{array}{l}\text { Autosomal } \\
\text { dominant with } \\
\text { variable penetrance }\end{array}$ & - \\
\hline Hägglund et al. [72] & 1986 & $\begin{array}{l}\text { Consecutive } \\
\text { case series }\end{array}$ & 50 (40 families) & $\begin{array}{c}8.1 \% \text { in } 1 \text { st } \\
\text { degree relatives }\end{array}$ & - & - \\
\hline $\begin{array}{l}\text { Hägglund and } \\
\text { Hansson [73] }\end{array}$ & 1986 & $\begin{array}{l}\text { Case report, } 3 \\
\text { generations }\end{array}$ & 3 cases, 1 family & - & $\begin{array}{c}\text { Autosomal } \\
\text { dominant with } \\
\text { variable penetrance }\end{array}$ & - \\
\hline Gajraj [74] & 1986 & $\begin{array}{l}\text { Case report, } \\
\text { identical } \\
\text { twins }\end{array}$ & 1 family, identical twins & - & - & $\mathrm{A} 11, \mathrm{~B} 12$ \\
\hline Mullaji et al. [75] & 1993 & $\begin{array}{l}\text { HLA testing } \\
\text { of SCFE } \\
\text { patients }\end{array}$ & 30 patients & - & - & $\begin{array}{l}\text { B27 in } 20 \%,> \\
\text { than in controls }\end{array}$ \\
\hline $\begin{array}{l}\text { Montskó and de } \\
\text { Jonge [76] }\end{array}$ & 1995 & Case report & $\begin{array}{c}1 \text { family father and } 5 \\
\text { siblings }(3 \mathrm{M}, 2 \mathrm{~F})\end{array}$ & - & - & - \\
\hline Moreira et al. [77] & 1998 & Case report & 1 family, 4 cases & - & $\begin{array}{c}\text { Autosomal } \\
\text { dominant }\end{array}$ & - \\
\hline Diwan et al. [78] & 1998 & Case report & 1 family, 2 generations & - & - & - \\
\hline $\begin{array}{l}\text { Bednarz and Stanitski } \\
{[79]}\end{array}$ & 1998 & Case report & Identical twins & - & - & $\begin{array}{l}\text { Twin 1: A2, 26, } \\
\text { B51, 60, Bw4/6 } \\
\text { Twin 2:A2,24, } \\
\text { B51/60, Bw4/6 }\end{array}$ \\
\hline Allen and Calvert [80] & 1990 & Case report & Identical twins & - & - & $\mathrm{A} 2, \mathrm{~B} 12$ \\
\hline Günal and Ateş [81] & 1997 & Case series & 6 patients & - & - & $\begin{array}{l}\text { DR4 common } \\
\text { to all; no other } \\
\text { common } \\
\text { phenotypes }\end{array}$ \\
\hline $\begin{array}{l}\text { Wong-Chung et al. } \\
{[82]}\end{array}$ & 2000 & $\begin{array}{l}\text { Random case } \\
\text { series }\end{array}$ & 7 cases, $6 \mathrm{M}, 1 \mathrm{~F}$ & $\begin{array}{l}2 \text { were } \\
\text { brothers }\end{array}$ & - & $\begin{array}{l}\text { No common } \\
\text { phenotypes }\end{array}$ \\
\hline Siemon et al. [83] & 2001 & Case report & Identical twins & 2 brothers & - & $\mathrm{A} 2$ \\
\hline Loder et al. [84] & 2005 & Case series & 9 cases_-Amish & $39 \%$ & & - \\
\hline $\begin{array}{l}\text { Sebastianowicz et al. } \\
{[85]}\end{array}$ & 2005 & Case report & Identical twins & 2 brothers & - & - \\
\hline Flores et al. [86] & 2006 & Case report & Identical twins & - & - & $\begin{array}{c}\text { A2, } 23(9), \text { B44 } \\
(12), 38(16) \\
\text { Bw4 Cw4, } 12 \\
\text { DR103, DQ5 (1) }\end{array}$ \\
\hline Lim et al. [87] & 2007 & Case report & Two brothers & - & Multifactorial & - \\
\hline
\end{tabular}


in anteversion compared to those with chronic SCFEs $\left(9.3^{\circ}\right.$ versus $\left.-0.7^{\circ}\right)$ in the involved hip and uninvolved hip $\left(15.7^{\circ}\right.$ versus $\left.11.8^{\circ}\right)$, with an average difference in version in acute SCFEs of $6.7^{\circ}$ and in chronic SCFEs of $13.9^{\circ}$ [128]. SCFE has no influence on acetabular development $[129,130]$. There are also no abnormalities in tibial torsion in children with stable SCFEs [131].

Genu recurvatum has been fleetingly described in SCFE $[132,133]$. It is believed that this represents a gradual anterior slip of the proximal tibial epiphysis, with the physes perhaps universally weak or susceptible to large stresses from obesity. Surprisingly, tibia vara (Blount's disease) is very rarely associated with SCFE [134-136] even though both conditions typically occur in obese children. Peroneal spastic flatfoot has been associated in certain cases with SCFE [137].

Increase width of the symphysis pubis and unaffected hip joint cartilage space has been observed [138], suggesting an abnormality of cartilage formation or maturation on a macroscopic level rather than a microscopic level. Skewness of the symphyseal joint has also been described on standing radiographs of the pelvis [139].

Other Nonskeletal Associations. Immune complexes in the synovial fluid and synovium of the hip, but not in the serum, have been found in a high percentage of SCFE cases $[140,141]$. This is different from the synovitis of the knee or hip caused by other disorders where immune complexes are rarely found. Fluorides in the water, used to reduce dental caries, also strengthen the physes and metaphyseal bone; however, no difference in the incidence of SCFE was seen in children with or without fluoride exposure [142].

\section{Conclusion}

The current incidence of SCFE ranges from $0.33 / 100,000$ to $24.58 / 100,000$ children 8 to 15 years of age, depending upon gender and ethnicity. There is significant variability within racial groups and the relative frequency, relative to Caucasians at 1.0, is 5.6 for Polynesians, 3.9 for Blacks, and 2.5 for Hispanics. The average age is 12.0 years for boys and 11.2 years for girls; obese children present earlier than light weighted children. The physiologic age range during which SCFE occurs is less variable than the chronologic age range. The average symptom duration for stable SCFEs is 4 to 5 months. Although there is a general correlation between symptom duration and SCFE severity, there is considerable variability. The majority of children are obese with $>50 \%$ of children $>95$ th percentile weight for age; the average BMI in SCFE children is $25-30 \mathrm{~kg} / \mathrm{m}^{2}$ or $>85$ th percentile. The onset of SCFE is in the summer months in latitudes north of $40^{\circ} \mathrm{N}$. Bilaterality ranges from 18 to $50 \%$ and is more frequent in Africans compared to Hispanic, White, and IndoMalay peoples. In children with bilateral involvement, 50$60 \%$ present with simultaneous SCFEs; $80-90 \%$ of those who present with a unilateral SCFE and subsequently develop a contralateral SCFE do so within 18 months after the first SCFE. The age at presentation is younger for those who present with a unilateral SCFE and develop contralateral involvement compared to those who do not develop a contralateral SCFE. The age-weight, age-height, and height test are useful to differentiate between an idiopathic and atypical SCFE.

\section{Acknowledgments}

This study was supported in part by the Garceau Professorship Endowment, Department of Orthopaedic Surgery, Indiana University School of Medicine, and the George Rapp Pediatric Orthopaedic Research Endowment, Riley Children's Foundation, Riley Children's Hospital, Indianapolis, Indiana. The authors otherwise have no financial interests with any other organizations or bodies. This was the last of three presentations on the epidemiology and demographics of Pediatric Hip Disorders given at the AO North American Symposium on Surgical Preservation of the Hip, Squaw Valley, California, January 2009.

\section{References}

[1] A. J. Schein, "Acute severe slipped capital femoral epiphysis," Clinical Orthopaedics and Related Research, vol. 51, pp. 151166, 1967.

[2] L. S. Segal, P. P. Weitzel, and R. S. Davidson, "Valgus slipped capital femoral epiphysis: fact or fiction?" Clinical Orthopaedics and Related Research, no. 322, pp. 91-98, 1996.

[3] R. T. Loder, P. W. O’Donnell, W. P. Didelot, and K. J. Kayes, "Valgus slipped capital femoral epiphysis," Journal of Pediatric Orthopaedics, vol. 26, no. 5, pp. 594-600, 2006.

[4] D. A. Yngve, D. L. Moulton, and E. B. Evans, "Valgus slipped capital femoral epiphysis," Journal of Pediatric Orthopaedics $B$, vol. 14, no. 3, pp. 172-176, 2005.

[5] R. T. Loder, B. Wittenberg, and G. DeSilva, "Slipped capital femoral epiphysis associated with endocrine disorders," Journal of Pediatric Orthopaedics, vol. 15, no. 3, pp. 349-356, 1995.

[6] D. Wells, J. D. King, T. F. Roe, and F. R. Kaufman, "Review of slipped capital femoral epiphysis associated with endocrine disease," Journal of Pediatric Orthopaedics, vol. 13, no. 5, pp. 610-614, 1993.

[7] P. C. McAfee and R. B. Cady, "Endocrinologic and metabolic factors in atypical presentations of slipped capital femoral epiphysis: report of four cases and review of the literature," Clinical Orthopaedics and Related Research, vol. 180, pp. 188196, 1983.

[8] R. T. Loder and R. N. Hensinger, "Slipped capital femoral epiphysis associated with renal failure osteodystrophy," Journal of Pediatric Orthopaedics, vol. 17, no. 2, pp. 205-211, 1997.

[9] R. T. Loder, R. N. Hensinger, P. D. Alburger et al., "Slipped capital femoral epiphysis associated with radiation therapy," Journal of Pediatric Orthopaedics, vol. 18, no. 5, pp. 630-636, 1998.

[10] S. C. Liu, C. C. Tsai, and C. H. Huang, "Atypical slipped capital femoral epiphysis after radiotherapy and chemotherapy," Clinical Orthopaedics and Related Research, no. 426, pp. 212218, 2004.

[11] A. Klein, R. J. Joplin, J. A. Reidy, and J. Hanelin, "Slipped capital femoral epiphysis; early diagnosis and treatment facilitated by normal roentgenograms," Journal of Bone and Joint Surgery, American, vol. 34, no. 1, pp. 233-239, 1952. 
[12] J. J. Fahey and E. T. O’Brien, “Acute slipped capital femoral epiphysis," Journal of Bone and Joint Surgery. American, vol. 47, pp. 1105-1127, 1965.

[13] D. D. Aronson and W. E. Carlson, "Slipped capital femoral epiphysis: a prospective study of fixation with a single screw," Journal of Bone and Joint Surgery, American, vol. 74, no. 6, pp. 810-819, 1992.

[14] W. T. Ward, J. Stefko, K. B. Wood, and C. L. Stanitski, "Fixation with a single screw for slipped capital femoral epiphysis," Journal of Bone and Joint Surgery, American, vol. 74, no. 6, pp. 799-809, 1992.

[15] R. J. Aadalen, D. S. Weiner, W. Hoyt, and C. H. Herndon, "Acute slipped capital femoral epiphysis," Journal of Bone and Joint Surgery, American, vol. 56, no. 7, pp. 1473-1487, 1974.

[16] D. W. Boyer, M. R. Mickelson, and I. V. Ponseti, "Slipped capital femoral epiphysis: long-term follow-up study of one hundred and twenty-one patients," Journal of Bone and Joint Surgery, American, vol. 63, no. 1, pp. 85-95, 1981.

[17] R. T. Loder, D. D. Aronson, and M. L. Greenfield, "The epidemiology of bilateral slipped capital femoral epiphysis: a study of children in Michigan," Journal of Bone and Joint Surgery, American, vol. 75, no. 8, pp. 1141-1147, 1993.

[18] R. T. Loder, B. S. Richards, P. S. Shapiro, L. R. Reznick, and D. D. Aronson, "Acute slipped capital femoral epiphysis: the importance of physeal stability," Journal of Bone and Joint Surgery, American, vol. 75, no. 8, pp. 1134-1140, 1993.

[19] P. E. Kallio, D. C. Paterson, B. K. Foster, and G. W. Lequesne, "Classification in slipped capital femoral epiphysis: sonographic assessment of stability and remodeling," Clinical Orthopaedics and Related Research, no. 294, pp. 196-203, 1993.

[20] P. E. Kallio, E. T. Mah, B. K. Foster, D. C. Paterson, and G. W. LeQuesne, "Slipped capital femoral epiphysis: incidence and clinical assessment of physeal instability," Journal of Bone and Joint Surgery, British, vol. 77, no. 5, pp. 752-755, 1995.

[21] G. T. Rab, "The geometry of slipped capital femoral epiphysis: implications for movement, impingement, and corrective osteotomy," Journal of Pediatric Orthopaedics, vol. 19, no. 4, pp. 419-424, 1999.

[22] H. H. Steel, "The metaphyseal blanch sign of slipped capital femoral epiphysis," Journal of Bone and Joint Surgery, American, vol. 68, no. 6, pp. 920-922, 1986.

[23] B. Jacobs, "Diagnosis and natural history of slipped capital femoral epiphysis," Instructional Course Lectures, vol. 21, pp. 167-173, 1972.

[24] R. T. Loder, L. C. Blakemore, F. A. Farley, and A. T. Laidlaw, "Measurement variability of slipped capital femoral epiphysis," Journal of Orthopaedic Surgery, vol. 7, no. 1, pp. 33-42, 1999.

[25] W. O. Southwick, "Osteotomy through the lesser trochanter for slipped capital femoral epiphysis," Journal of Bone and Joint Surgery, American, vol. 49, no. 5, pp. 807-835, 1967.

[26] B. T. Carney, S. L. Weinstein, and J. Noble, "Long-term follow-up of slipped capital femoral epiphysis," Journal of Bone and Joint Surgery, American, vol. 73, no. 5, pp. 667-674, 1991.

[27] B. T. Carney and S. L. Weinstein, "Natural history of untreated chronic slipped capital femoral epiphysis," Clinical Orthopaedics and Related Research, no. 322, pp. 43-47, 1996.

[28] V. Guzzanti and F. Falciglia, "Slipped capital femoral epiphysis: comparison of a roentgenographic method and computed tomography in determining slip severity," Journal of Pediatric Orthopaedics, vol. 11, no. 1, pp. 6-12, 1991.
[29] N. S. Stott and T. A. Bidwell, "Epidemiology of slipped capital femoral epiphysis in a population with a high proportion of New Zealand Maori and Pacific children," New Zealand Medical Journal, vol. 116, no. 1184, pp. 1-8, 2003.

[30] R. T. Loder, "The demographics of slipped capital femoral epiphysis: an international multicenter study," Clinical Orthopaedics and Related Research, no. 322, pp. 8-27, 1996.

[31] C. L. Lehmann, R. R. Arons, R. T. Loder, and M. G. Vitale, "The epidemiology of slipped capital femoral epiphysis: an update," Journal of Pediatric Orthopaedics, vol. 26, no. 3, pp. 286-290, 2006.

[32] E. C. Benson, M. Miller, P. Bosch, and E. A. Szalay, "A new look at the incidence of slipped capital femoral epiphysis in New Mexico," Journal of Pediatric Orthopaedics, vol. 28, no. 5, pp. 529-533, 2008.

[33] Y. J. Lim, F. Kagda, K. S. Lam et al., "Demographics and clinical presentation of slipped capital femoral epiphysis in Singapore: comparing the East with the West," Journal of Pediatric Orthopaedics B, vol. 17, no. 6, pp. 289-292, 2008.

[34] G. Hägglund, L. I. Hansson, and G. Ordeberg, "Epidemiology of slipped capital femoral epiphysis in southern Sweden," Clinical Orthopaedics and Related Research, vol. 191, pp. 8294, 1984.

[35] D. S. Weiner, S. Weiner, A. Melby, and W. A. Hoyt Jr., "A 30-year experience with bone graft epiphysiodesis in the treatment of slipped capital femoral epiphysis," Journal of Pediatric Orthopaedics, vol. 4, no. 2, pp. 145-152, 1984.

[36] S. Ninomiya, Y. Nagasaka, and H. Tagawa, "Slipped capital femoral epiphysis: a study of 68 cases in the eastern half area of Japan," Clinical Orthopaedics and Related Research, vol. 119, pp. 172-176, 1976.

[37] J. L. Kelsey, K. J. Keggi, and W. O. Southwick, "The incidence and distrubition of slipped capital femoral epiphysis in Connecticut and southwestern United States," Journal of Bone and Joint Surgery, American, vol. 52, no. 6, pp. 1203-1216, 1970.

[38] Y. Noguchi and T. Sakamaki, "Epidemiology and demographics of slipped capital femoral epiphysis in Japan: a multicenter study by the Japanese Paediatric Orthopaedic Association," Journal of Orthopaedic Science, vol. 7, no. 6, pp. 610-617, 2002.

[39] A. N. Larson, E. M. Yu, L. J. Melton, H. A. Peterson, and A. A. Stans, "Incidence of slipped capital femoral epiphysis: a population-based study," Journal of Pediatric Orthopaedics B, vol. 19, no. 1, pp. 9-12, 2010.

[40] A. W. Murray and N. I. L. Wilson, "Changing incidence of slipped capital femoral epiphysis: a relationship with obesity?" Journal of Bone and Joint Surgery, British, vol. 90, no. 1, pp. 92-94, 2008.

[41] J. L. Kelsey, "The incidence and distribution of slipped capital femoral epiphysis in Connecticut," Journal of Chronic Diseases, vol. 23, no. 8, pp. 567-578, 1971.

[42] R. Jerre, J. Karlsson, and B. Henrikson, "The incidence of physiolysis of the hip: a population-based study of 175 patients," Acta Orthopaedica Scandinavica, vol. 67, pp. 53-56, 1996.

[43] B. Henrikson, "The incidence of slipped capital femoral epiphysis," Acta Orthopaedica Scandinavica, vol. 40, pp. 365372, 1969.

[44] K.-S. Song, C.-W. Oh, H-.J. Lee, and S.-D. Kim, "Epidemiology and demographics of slipped capital femoral epiphysis in Korea: a multicenter study by the Korean Pediatric 
Orthopaedic Society," Journal of Pediatric Orthopaedics, vol. 29, pp. 683-686, 2009.

[45] D. D. Aronson and R. T. Loder, "Slipped capital femoral epiphysis in black children," Journal of Pediatric Orthopaedics, vol. 12, no. 1, pp. 74-79, 1992.

[46] R. T. Loder, T. Starnes, G. Dikos, and D. D. Aronsson, "Demographic predictors of severity of stable slipped capital femoral epiphyses," Journal of Bone and Joint Surgery, American, vol. 88, no. 1, pp. 97-105, 2006.

[47] H. J. Burrows, "Slipped upper femoral epiphysis: characteristics of a hundred cases," Journal of Bone and Joint Surgery, British, vol. 39, pp. 641-658, 1957.

[48] H. Carlioz, J. C. Vogt, L. Barba, and L. Doursounian, "Treatment of slipped upper femoral epiphysis: 80 cases operated on over 10 years (1968-1978)," Journal of Pediatric Orthopaedics, vol. 4, no. 2, pp. 153-161, 1984.

[49] D. D. Aronson, D. A. Peterson, and D. V. Miller, "Slipped capital femoral epiphysis: the case for internal fixation in situ," Clinical Orthopaedics and Related Research, no. 281, pp. 115-122, 1992.

[50] C. R. Dreghorn, D. Knight, C. C. Mainds, and N. J. Blockey, "Slipped upper femoral epiphysis: a review of 12 years of experience in Glasgow (1972-1983)," Journal of Pediatric Orthopaedics, vol. 7, no. 3, pp. 283-287, 1987.

[51] R. G. Kulick and J. R. Denton, "A retrospective study of 125 cases of slipped capital femoral epipysis," Clinical Orthopaedics and Related Research, vol. 162, pp. 87-90, 1982.

[52] K. J. Koval, W. B. Lehman, D. Rose, R. P. Koval, A. Grant, and A. Strongwater, "Treatment of slipped capital femoral epiphysis with a cannulated-screw technique," Journal of Bone and Joint Surgery, American, vol. 71, no. 9, pp. 13701377, 1989.

[53] P. B. Eveleth and J. M. Tanner, Worldwide Variation in Human Growth, University Press, Cambridge, UK, 2nd edition, 1990.

[54] H. K. Kitadai, C. Milani, C. A. S. Nery, and J. L. Filho, "Wiberg's center-edge angle in patients with slipped capital femoral epiphysis," Journal of Pediatric Orthopaedics, vol. 19, no. 1, pp. 97-105, 1999.

[55] R. T. Loder, A. A. Mehbod, C. Meyer, and M. Meisterling, "Acetabular depth and race in young adults: a potential explanation of the differences in the prevalence of slipped capital femoral epiphysis between different racial groups?" Journal of Pediatric Orthopaedics, vol. 23, no. 6, pp. 699-702, 2003.

[56] R. T. Loder, T. Starnes, and G. Dikos, "The narrow window of bone age in children with slipped capital femoral epiphysis: a reassessment one decade later," Journal of Pediatric Orthopaedics, vol. 26, no. 3, pp. 300-306, 2006.

[57] L. I. Hansson, G. Hägglund, and G. Ordeberg, "Slipped capital femoral epiphysis in southern Sweden 1910-1982," Acta Orthopaedica Scandinavica, vol. 58, supplement 226, pp. 9-67, 1987.

[58] N. Maffulli and A. S. Douglas, "Seasonal variation of slipped capital femoral epiphysis," Journal of Pediatric Orthopaedics B, vol. 11, no. 1, pp. 29-33, 2002.

[59] R. T. Loder, "A worldwide study on the seasonal variation of slipped capital femoral epiphysis," Clinical Orthopaedics and Related Research, vol. 322, no. 322, pp. 28-36, 1996.

[60] R. T. Loder, D. D. Aronson, and R. O. Bollinger, "Seasonal variation of slipped capital femoral epiphysis," Journal of Bone and Joint Surgery, American, vol. 72, no. 3, pp. 378-381, 1990.
[61] D. Brown, "Seasonal variation of slipped capital femoral epiphysis in the United States," Journal of Pediatric Orthopaedics, vol. 24, no. 2, pp. 139-143, 2004.

[62] L. Andrén and K.-E. Borgström, "Seasonal variation of epiphysiolysis of the hip and possible causative factor," Acta Orthopaedica Scandinavica, vol. 28, pp. 22-26, 1959.

[63] R. T. Loder, F. A. Farley, J. E. Herzenberg, R. N. Hensinger, and J. L. Kuhn, "Narrow window of bone age in children with slipped capital femoral epiphyses," Journal of Pediatric Orthopaedics, vol. 13, no. 3, pp. 290-293, 1993.

[64] A. Thrap-Meyer, "Epiphysiolysis capitis femoris in two generations: casuistic report," Acta Orthopaedica Scandinavica, vol. 11, pp. 1-10, 1940.

[65] C. G. Irwin, "Unilateral adolescent coxa vara," Journal of Bone and Joint Surgery. British, vol. 28, p. 653, 1946.

[66] W. S. Smith, "Slipped upper femoral epiphysis in siblings," The Ohio State Medical Journal, vol. 51, pp. 1200-1201, 1955.

[67] P. D. Wilson, B. Jacobs, and L. Schecter, "Slipped capital femoral epiphysis: an end-result study," Journal of Bone and Joint Surgery, American, vol. 47, pp. 1128-1145, 1965.

[68] A. M. Rennie, "Familial slipped upper femoral epiphysis," Journal of Bone and Joint Surgery. British, vol. 49, no. 3, pp. 535-539, 1967.

[69] P. E. Ochsner, R. Razavi, and A. Schnizel, "Slipped capital femoral epiphyses in ten members of one family: probably autosomal dominant transmission with variable penetrance," Zeitschrift für Orthopädie und Ihre Grenzgebiete, vol. 27, pp. 147-150, 1977.

[70] R. L. Gorin, "Slipped capital femoral epiphyses in indentical twins: report of a case," Journal of the American Osteopathic Association, vol. 77, pp. 124-128, 1977.

[71] A. M. Rennie, "The inheritance of slipped upper femoral epiphysis," Journal of Bone and Joint Surgery, British, vol. 64, no. 2, pp. 180-184, 1982.

[72] G. Hägglund, L. I. Hansson, and S. Sandström, "Familial slipped capital femoral epiphysis," Acta Orthopaedica Scandinavica, vol. 57, no. 6, pp. 510-512, 1986.

[73] G. Hägglund and L. I. Hansson, "Slipped capital femoral epiphysis in three generations," Acta Orthopaedica Scandinavica, vol. 57, no. 3, pp. 240-242, 1986.

[74] H. A. R. Gajraj, "Slipped capital femoral epiphyses in identical twins," Journal of Bone and Joint Surgery, British, vol. 68, no. 4, pp. 653-654, 1986.

[75] A. B. Mullaji, R. J. H. Emery, V. C. Joysey, R. C. Todd, and N. Rushton, "HLA and slipped capital femoral epiphysis," Journal of Orthopaedic Rheumatology, vol. 6, no. 4, pp. 167169, 1993.

[76] P. Montskó and T. de Jonge, "Slipped capital femoral epiphysis in 6 of 8 first-degree relatives," Acta Orthopaedica Scandinavica, vol. 66, pp. 511-512, 1995.

[77] J. F. Moreira, M. C. Neves, G. Lopes, and A. R. Gomes, "Slipped capital femoral epiphysis: a report of 4 cases occurring in one family," International Orthopaedics, vol. 22, no. 3, pp. 193-196, 1998.

[78] A. Diwan, D. Diamond, R. Clarke, M. K. Patel, G. A. C. Murrell, and R. Sekel, "Familial slipped capital femoral epiphysis: a report and considerations in management," Australian and New Zealand Journal of Surgery, vol. 68, no. 9, pp. 647-649, 1998.

[79] P. A. Bednarz and C. L. Stanitski, "Slipped capital femoral epiphysis in identical twins: HLA predisposition," Orthopedics, vol. 21, no. 12, pp. 1291-1293, 1998. 
[80] C. P. F. Allen and P. T. Calvert, "Simultaneous slipped upper femoral epiphysis in identical twins," Journal of Bone and Joint Surgery, British, vol. 72, no. 5, pp. 928-929, 1990.

[81] I. Günal and E. Ateş, "The HLA phenotype in slipped capital femoral epiphysis," Journal of Pediatric Orthopaedics, vol. 17, no. 5, pp. 655-656, 1997.

[82] J. Wong-Chung, Y. Al-Aali, I. Farid, and A. Al-Aradi, "A common HLA phenotype in slipped capital femoral epiphysis?" International Orthopaedics, vol. 24, no. 3, pp. 158-159, 2000.

[83] B. Siemon, F. Pfannenschimd, and H. P. Jüsten, "Epiphyseolysis capitis femoris (CFE) in monozygotic twins," Zeitschrift für Orthopädie und Ihre Grenzgebiete, vol. 139, pp. 245-247, 2001.

[84] R. T. Loder, J. Nechleba, J. O. Sanders, and P. Doyle, "Idiopathic slipped capital femoral epiphysis in Amish children," Journal of Bone and Joint Surgery, American, vol. 87, no. 3, pp. 543-549, 2005.

[85] P. Sebastianowicz, A. Rymarczyk, M. Tȩsiorowski, B. Jasiewicz, W. Kạcki, and D. Zarzycki, "Slipped capital femoral epiphysis in identical twins: a case report," Ortopedia Traumatologia Rehabilitacja, vol. 7, pp. 92-98, 2005.

[86] M. Flores, S. G. Satish, and T. Key, "Slipped capital femoral epiphysis in identical twins: is there an HLA predisposition? Report of a case and review of the literature," Bulletin of the Hospital for Joint Diseases, vol. 63, no. 3-4, pp. 158-160, 2006.

[87] Y.-J. Lim, K. S. Lam, and E. H. Lee, "Slipped capital femoral epiphysis in two Indian brothers: the inheritance of slipped capital femoral epiphysis reviewed," Annals of the Academy of Medicine Singapore, vol. 36, no. 10, pp. 873-874, 2007.

[88] M. S. Kocher, J. A. Bishop, B. Weed et al., "Delay in diagnosis of slipped capital femoral epiphysis," Pediatrics, vol. 113, no. 4, pp. e322-e325, 2004.

[89] M. J. Matava, C. M. Patton, S. Luhmann, J. E. Gordon, and P. L. Schoenecker, "Knee pain as the initial symptom of slipped capital femoral epiphysis: an analysis of initial presentation and treatment," Journal of Pediatric Orthopaedics, vol. 19, no. 4, pp. 455-460, 1999.

[90] D. Rahme, A. Comley, B. Foster, and P. Cundy, "Consequences of diagnostic delays in slipped capital femoral epiphysis," Journal of Pediatric Orthopaedics B, vol. 15, no. 2, pp. 93-97, 2006.

[91] S. Ankarath, A. B. Y. Ng, P. V. Giannoudis, and B. W. Scott, "Delay in diagnosis of slipped upper femoral epiphysis," Journal of the Royal Society of Medicine, vol. 95, no. 7, pp. 356-358, 2002.

[92] C. A. Ledwith and G. R. Fleisher, "Slipped capital femoral epiphysis without hip pain leads to missed diagnosis," Pediatrics, vol. 89, no. 4, pp. 660-662, 1992.

[93] R. T. Loder, "Correlation of radiographic changes with disease severity and demographic variables in children with stable slipped capital femoral epiphysis," Journal of Pediatric Orthopaedics, vol. 28, no. 3, pp. 284-290, 2008.

[94] J. L. Kelsey, R. M. Acheson, and K. J. Keggi, “The body build of patients with slipped capital femoral epiphysis," American Journal of Diseases of Children, vol. 124, no. 2, pp. 276-281, 1972.

[95] G. Hägglund, L. I. Hansson, V. Hansson, and J. Karlberg, "Growth of children with physiolysis of the hip," Acta Orthopaedica Scandinavica, vol. 58, pp. 117-120, 1987.

[96] P. G. Wilcox, D. S. Weiner, and B. Leighley, "Maturation factors in slipped capital femoral epiphysis," Journal of Pediatric Orthopaedics, vol. 8, no. 2, pp. 196-200, 1988.
[97] C. BMI, BMI Calculator, 2001, http://www.keepkidshealthy .com/welcome/bmicalculator.html.

[98] BMI fCaT, BMI for Children and Teens, 2003, http:// www.cdc.gov/healthyweight/assessing/bmi/childrens_bmi/ about_childrens_bmi.html.

[99] N. N. Bhatia, M. Pirpiris, and N. Y. Otsuka, "Body mass index in patients with slipped capital femoral epiphysis," Journal of Pediatric Orthopaedics, vol. 26, no. 2, pp. 197-199, 2006.

[100] E. M. Manoff, M. B. Banffy, and J. J. Winell, "Relationship between body mass index and slipped capital femoral epiphysis," Journal of Pediatric Orthopaedics, vol. 25, no. 6, pp. 744-746, 2005.

[101] M. Poussa, D. Schlenzka, and T. Yrjönen, "Body mass index and slipped capital femoral epiphysis," Journal of Pediatric Orthopaedics B, vol. 12, no. 6, pp. 369-371, 2003.

[102] M. A. Kamarulzaman, A. R. Abdul-Halim, and S. Ibrahim, "Slipped capital femoral epiphysis (SCFE): a 12-year review," Medical Journal of Malaysia, vol. 61, supplement A, pp. 7178, 2006.

[103] R. H. Gelberman, M. S. Cohen, B. A. Shaw, J. R. Kasser, P. P. Griffin, and R. H. Wilkinson, "The association of femoral retroversion with slipped capital femoral epiphysis," Journal of Bone and Joint Surgery, American, vol. 68, pp. 1000-1007, 1986.

[104] R. T. Galbraith, R. H. Gelberman, P. C. Hajek et al., "Obesity and decreased femoral anteversion in adolescence," Journal of Orthopaedic Research, vol. 5, no. 4, pp. 523-528, 1987.

[105] D. Weiner, "Pathogenesis of slipped capital femoral epiphysis: current concepts," Journal of Pediatric Orthopaedics B, vol. 5, no. 2, pp. 67-73, 1996.

[106] A. B. Ferguson and M. B. Howorth, "Slipping of the upper femoral epiphysis," The Journal of the American Medical Association, vol. 97, pp. 1867-1872, 1931.

[107] E. Morscher, "Strength and morphology of growth cartilage under hormonal influence of puberty," Reconstruction Surgery and Traumatology, vol. 10, pp. 1-103, 1968.

[108] R. T. Loder and M. L. V. H. Greenfield, "Clinical characteristics of children with atypical and idiopathic slipped capital femoral epiphysis: description of the age-weight test and implications for further diagnostic investigation," Journal of Pediatric Orthopaedics, vol. 21, no. 4, pp. 481-487, 2001.

[109] R. Jerre, L. Billing, G. Hansson, and J. Wallin, "The contralateral hip in patients primarily treated for unilateral slipped upper femoral epiphysis: long-term follow-up of 61 hips," Journal of Bone and Joint Surgery, British, vol. 76, no. 4, pp. 563-567, 1994.

[110] R. Jerre, L. Billing, G. Hansson, J. Karlsson, and J. Wallin, "Bilaterality in slipped capital femoral epiphysis: importance of a reliable radiographic method," Journal of Pediatric Orthopaedics B, vol. 5, no. 2, pp. 80-84, 1996.

[111] P. Koczewski, "An epidemiological analysis of bilateral slipped capital femoral epiphysis in children," Chirurgia Narzadow Ruchu I Ortopedia Polska, vol. 66, no. 4, pp. 357364, 2001.

[112] J. M. Hurley, R. R. Betz, R. T. Loder, R. S. Davidson, P. D. Alburger, and H. H. Steel, "Slipped capital femoral epiphysis: the prevalence of late contralateral slip," Journal of Bone and Joint Surgery, American, vol. 78, no. 2, pp. 226-230, 1996.

[113] P. J. Stasikelis, C. M. Sullivan, W. A. Phillips, and J. A. Polard, "Slipped capital femoral epiphysis: prediction of contralateral involvement," Journal of Bone and Joint Surgery, American, vol. 78, no. 8, pp. 1149-1155, 1996.

[114] L. S. Segal, R. S. Davidson, W. W. J. Robertson, and D. S. Drummond, "Growth disturbances of the proximal femur 
after pinning of juvenile slipped capital femoral epiphysis," Journal of Pediatric Orthopaedics, vol. 11, no. 5, pp. 631-637, 1991.

[115] J. Riad, G. Bajelidze, and P. G. Gabos, "Bilateral slipped capital femoral epiphysis: predictive factors for contralateral slip," Journal of Pediatric Orthopaedics, vol. 27, no. 4, pp. 411414, 2007.

[116] T. A. Bidwell and N. S. Stott, "Sequential slipped capital femoral epiphyses: who is at risk for a second slip?" Aus NZ Journal of Surgery, vol. 76, no. 11, pp. 973-976, 2006.

[117] D. Puylaert, A. Dimeglio, and T. Bentahar, "Staging puberty in slipped capital femoral epiphysis: importance of the triradiate cartilage," Journal of Pediatric Orthopaedics, vol. 24, no. 2, pp. 144-147, 2004.

[118] K. M. Koenig, J. D. Thomson, K. L. Anderson, and B. T. Carney, "Does skeletal maturity predict sequential contralateral involvement after fixation of slipped capital femoral epiphysis?" Journal of Pediatric Orthopaedics, vol. 27, no. 7, pp. 796-800, 2007.

[119] C. Barrios, M. A. Blasco, M. C. Blasco, and J. Gascó, "Posterior sloping angle of the capital femoral physis: a predictor of bilaterality in slipped capital femoral epiphysis," Journal of Pediatric Orthopaedics, vol. 25, no. 4, pp. 445-449, 2005.

[120] M. Zenios, M. Ramachandran, M. Axt, P. J. Gibbons, J. Peat, and D. Little, "Posterior sloping angle of the capital femoral physis: interobserver and intraobserver reliability testing and predictor of bilaterality," Journal of Pediatric Orthopaedics, vol. 27, no. 7, pp. 801-804, 2007.

[121] K. H. Sørensen, "Slipped upper femoral epiphysis: clinical study on aetiology," Acta Orthopaedica Scandinavica, vol. 39, no. 4, pp. 499-517, 1968.

[122] E. Ali and D. Ledford, "Slipped capital femoral epiphysis at the University Hospital of The West Indies," West Indian Medical Journal, vol. 30, no. 4, pp. 211-214, 1981.

[123] R. M. Szabo, "Principles of epidemiology for the orthopaedic surgeon," Journal of Bone and Joint Surgery, American, vol. 80, no. 1, pp. 111-120, 1998.

[124] S. R. Burrow, B. Alman, and J. G. Wright, "Short stature as a screening test for endocrinopathy in slipped capital femoral epiphysis," Journal of Bone and Joint Surgery, British, vol. 83, no. 2, pp. 263-268, 2001.

[125] R. T. Loder, T. Starnes, and G. Dikos, "Atypical and typical (idiopathic) slipped capital femoral epiphysis: reconfirmation of the age-weight test and description of the height and age-height tests," Journal of Bone and Joint Surgery, American, vol. 88, no. 7, pp. 1574-1581, 2006.

[126] J. Kordelle, M. Millis, F. A. Jolesz, R. Kikinis, and J. A. Richolt, "Three-dimensional analysis of the proximal femur in patients with slipped capital femoral epiphysis based on computed tomography," Journal of Pediatric Orthopaedics, vol. 21, no. 2, pp. 179-182, 2001.

[127] M. Jacquemier, P. Noca, R. Dick et al., "Femoral anteversion in slipped capital femoral epiphysis: a CT-scan study in 25 cases," Revue de Chirurgie Orthopédique et Réparatrice de l'Appareil Moteur, vol. 77, no. 8, pp. 530-536, 1991.

[128] C. L. Stanitski, R. Woo, and D. F. Stanitiski, "Femoral version in acute slipped capital femoral epiphysis," Journal of Pediatric Orthopaedics B, vol. 5, pp. 74-76, 1996.

[129] J. Kordelle, J. A. Richolt, M. Millis, F. A. Jolesz, and R. Kikinis, "Development of the acetabulum in patients with slipped capital femoral epiphysis: a three-dimensional analysis based on computed tomography," Journal of Pediatric Orthopaedics, vol. 21, no. 2, pp. 174-178, 2001.
[130] C. L. Stanitski, R. Woo, and D. F. Stanitiski, "Acetabular version in slipped capital femoral epiphysi: a prospective study," Journal of Pediatric Orthopaedics B, vol. 5, pp. 77-79, 1996.

[131] C. L. Stanitski, C. S. Litts, and D. F. Stanitski, "Tibial torsion in chronic, stable slipped capital femoral epiphyses: evaluation by CT scan," Journal of Pediatric Orthopaedics, vol. 17, no. 5, pp. 657-658, 1997.

[132] P. H. Gibson, "Genu recurvatum in association with slipped capital femoral epiphysis," Journal of the Royal Society of Medicine, vol. 74, no. 8, pp. 626-627, 1981.

[133] K. Rechnagel, "Genu recurvatum associated with slipped capital femoral epiphysis," Acta Orthopaedica Scandinavica, vol. 44, pp. 505-508, 1973.

[134] J. R. Bowen, M. Assis, K. Sinha, S. Hassink, and A. Littleton, "Associations among slipped capital femoral epiphysis, tibia vara, and type 2 juvenile diabetes," Journal of Pediatric Orthopaedics, vol. 29, no. 4, pp. 341-344, 2009.

[135] J. F. Lovejoy Jr. and W. W. Lovell, “Adolescent tibia vara associated with slipped capital femoral epiphysis: a report of two cases," Journal of Bone and Joint Surgery, American, vol. 52, no. 2, pp. 361-364, 1970.

[136] K. Takikawa and N. Haga, "Slipped capital femoral epiphysis following contralateral infantile Blount's disease," Journal of Orthopaedic Science, vol. 7, no. 3, pp. 403-404, 2002.

[137] S. G. Doig and M. B. Menelaus, "Association of slipped upper femoral epiphysis and peroneal spastic flatfoot," Journal of Pediatric Orthopaedics, vol. 11, no. 2, pp. 220-221, 1991.

[138] B. Tins, V. Cassar-Pullicino, and M. Haddaway, "Symphysis pubis width and unaffected hip joint width in patients with slipped upper femoral epiphysis: widening compared with normal values," Skeletal Radiology, vol. 39, no. 4, pp. 353$357,2010$.

[139] G. Theander, "Pelvic instability in upper femoral epihyseolysis," Acta Orthopaedica Scandinavica, vol. 32, pp. 52-59, 1962.

[140] R. T. Morrissy, A. E. Kalderon, and M. H. Gerdes, "Synovial immunoflourescence in patients with slipped capital femoral epiphyses," Journal of Pediatric Orthopaedics, vol. 1, pp. 5560, 1981.

[141] R. T. Morrissy, R. W. Steele, and M. H. Gerdes, "Localised immune complexes and slipped upper femoral epiphysis," Journal of Bone and Joint Surgery, British, vol. 65, no. 5, pp. 574-579, 1983.

[142] J. L. Kelsey and K. J. Keggi, "An epidemiological study of the effect of fluorides in drinking water on the frequency of slipped capital femoral epiphysis," Yale Journal of Biology and Medicine, vol. 44, no. 3, pp. 274-285, 1971. 


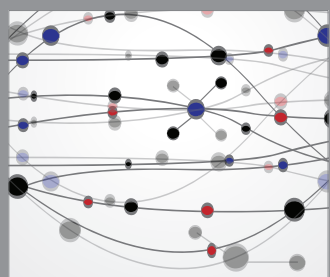

The Scientific World Journal
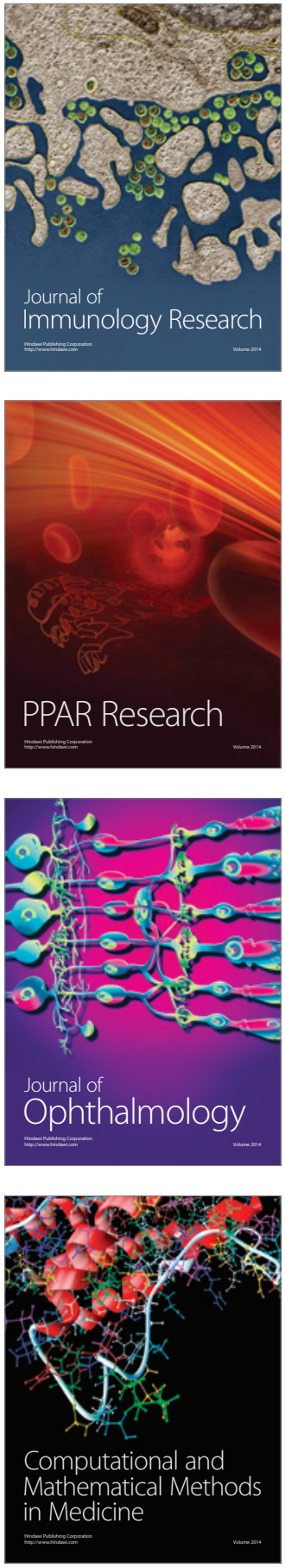

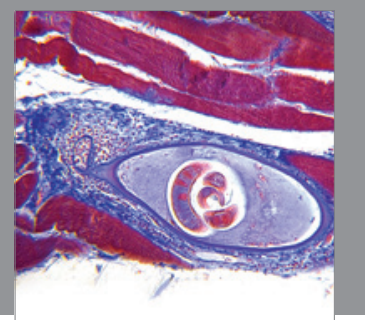

Gastroenterology

Research and Practice
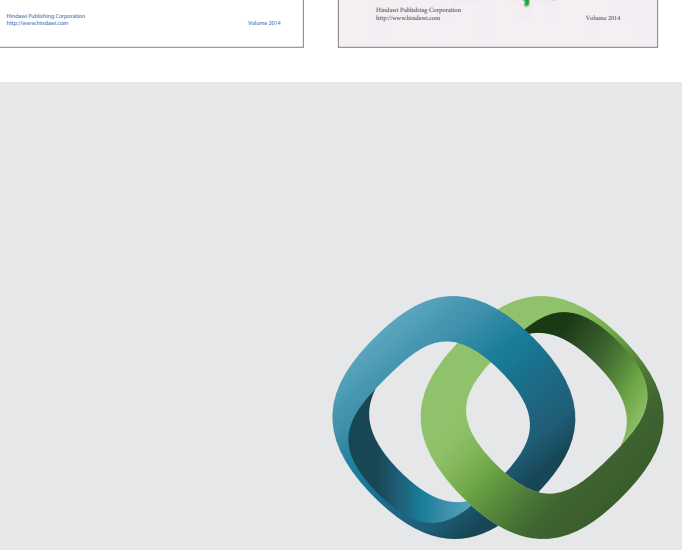

\section{Hindawi}

Submit your manuscripts at

http://www.hindawi.com
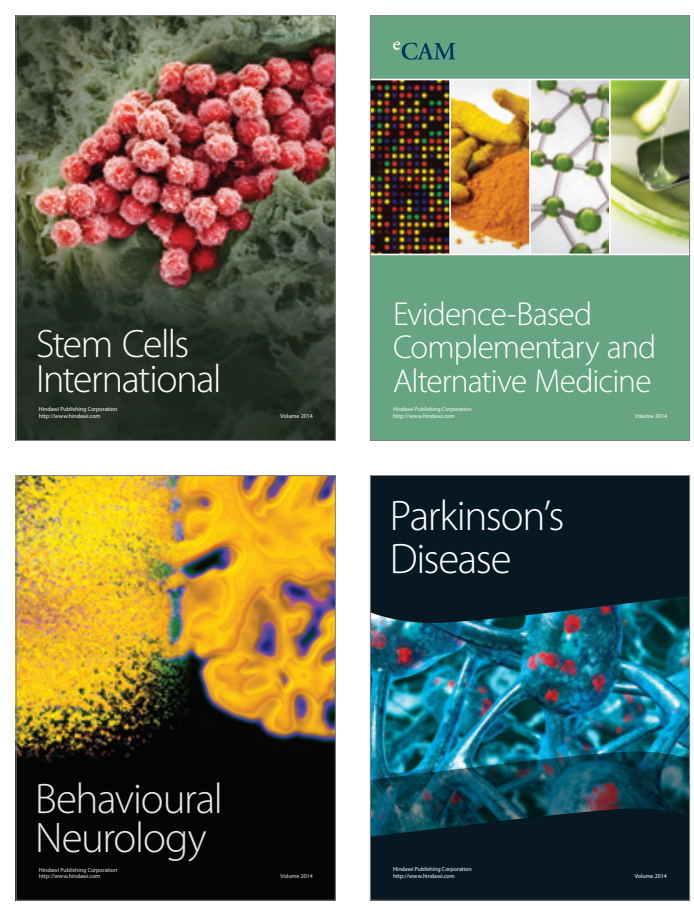

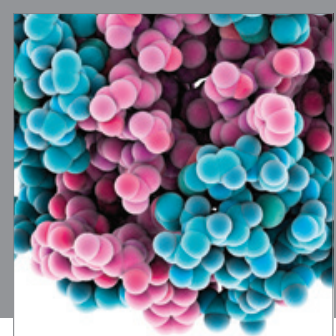

Journal of
Diabetes Research

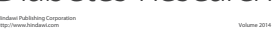

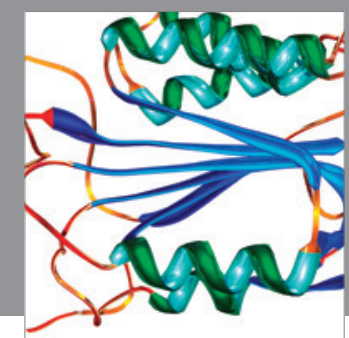

Disease Markers
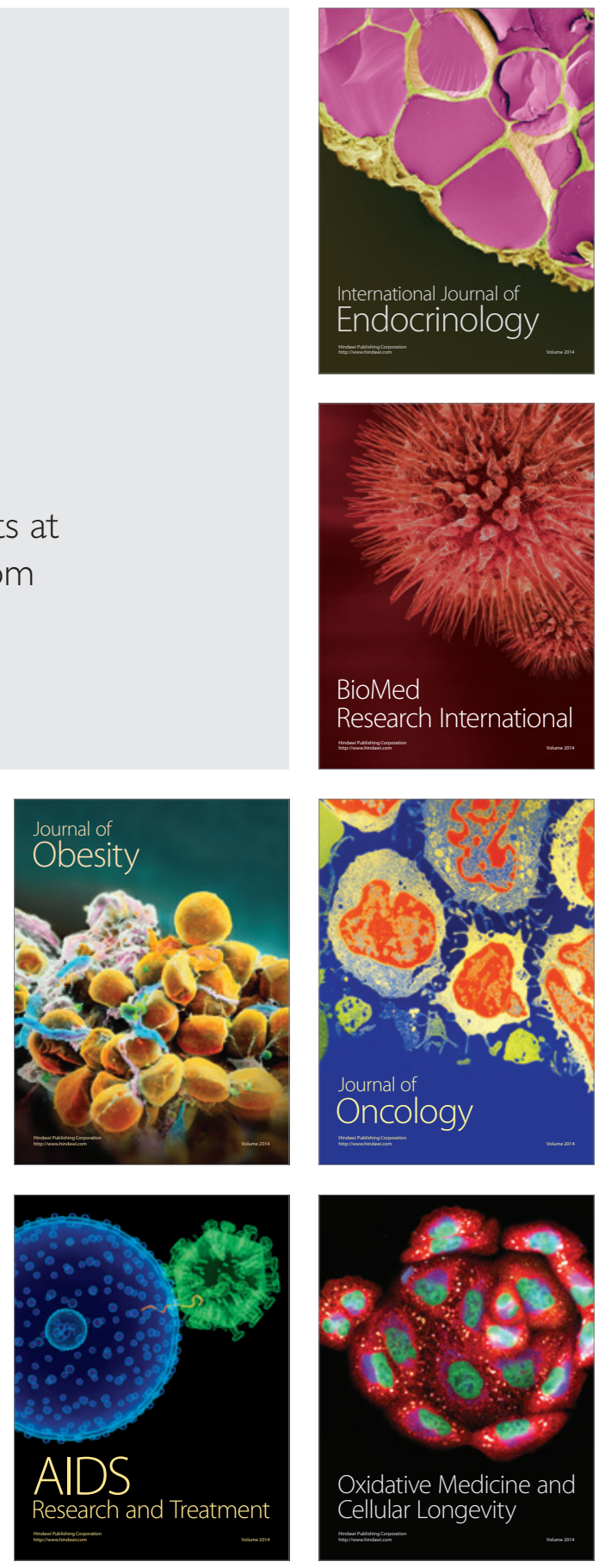